\title{
PENGARUH STRATEGI PELATIHAN DAN PENGETAHUAN KONSEP DASAR EKOLOGI TERHADAP SIKAP TENAGA KERJA YANG BERWAWASAN LINGKUNGAN
}

\author{
(Eksperimen pada Tenaga Kerja Indonesia di Balai Latihan Kerja Daerah Jakarta Barat (2006))
}

\author{
J. E. Endang D. P
}

Staf Dinas Tenaga Kerja dan Transmigrasi Provinsi DKI Jakarta

\begin{abstract}
This study aimed at investigating the effect of training strategies and knowledge of basic concepts of ecology on environmental-based attitude of prospective labors. The experimental study with $2 \times 2$ factorial designs was conducted at the Regional Labor Training Centre of West Jakarta with training participants of the center involved as subjects of the study. The study has been focused on four Research Questions: (1) Is there any significant difference in the environmental-based attitude of prospective labors who were trained with fieldtrip strategy and those who were trained with group discussion strategy?; (2) Is there any significant difference in the environmental-based attitude of prospective labors with high level of knowledge of basic concepts of ecology who were trained with fieldtrip strategy and those who were trained with group discussion strategy?; (3) Is there any in the environmental-based attitude of prospective labors with low level of knowledge of basic concepts of ecology who were trained with fieldtrip strategy and those who were trained with group discussion strategy?; and (4) Is there any interactions between the effect of training strategies and knowledge of basic concepts of ecology on the environmental-based attitude of prospective labors?

Findings of the study signify that (1) there is no significant difference in the environmentalbased attitude of prospective labors who were trained with fieldtrip strategy and those who were trained with group discussion strategy; (2) prospective labors with high level of knowledge of basic concepts of ecology who were trained with fieldtrip strategy show better environmental-based attitude compared to those who were trained with group discussion strategy; (3) prospective labors with low level of knowledge of basic concepts of ecology who were trained with group discussion strategy show better environmental-based attitude compared to those who were trained with fieldtrip strategy; and (4) there is an interaction between training strategies and knowledge of basic concepts of ecology on the environmental-based attitude of prospective labors.

To sum up, to promote better environmental-based attitude of prospective labors requires appropriate training strategies that is determined by carefully considering their knowledge level on basic concepts of ecology.
\end{abstract}

\section{PENDAHULUAN}

Indonesia sebagai salah satu negara berkembang, memiliki potensi sumber daya alam yang besar, juga memiliki jumlah penduduk terbesar ketiga di dunia, namun pada kenyataannya kekayaan alam dan jumlah penduduk yang besar belum menjadi potensi yang dapat dimanfaatkan bagi kesejahteraan bangsa khususnya dalam memanfaatkan sumber daya tersebut secara bijaksana.

Jumlah penduduk Indonesia menurut hasil sensus penduduk tahun 2007 tercatat 234,693,997 jiwa dengan laju pertumbuhan penduduk sebesar 1,35\%. Angka pertumbuhan tersebut apabila dikaji semenjak sensus tahun 1980 telah terjadi penurunan laju pertumbuhan sebesar 0,62\% (BPS, 2006: pp 4-5). Salah satu faktor yang mempengaruhi menurunnya laju pertumbuhan penduduk adalah menurunnya angka kelahiran dan angka kematian berkisar antara $14-17 \%$ pertahun. Situasi ini menunjukkan bahwa besaran jumlah penduduk berada pada golongan usia produktif antara kisaran umur 15 44 tahun.

Laporan BPS tahun 2005 kelompok usia produktif tersebut mencapai angka 42.597 .612 jiwa, dengan frekuensi tertinggi pada tingkat usia kerja 15-24 tahun sebanyak 22.756.822 jiwa (BPS, 2007: www.menakertrans.go.id). Kondisi usia kerja pada kisaran umur ini sesuai pada tahapan pendidikan formal, maka dapat berada antara tenaga kerja lulusan Sekolah Menengah, baik sekolah menengah umum maupun sekolah menengah kejuruan, dan Sekolah/Perguruan Tinggi. Hal ini menunjukkan bahwa tingkat kematangan dalam kapasitas kerja pada tingkat usia kerja ini dengan tingkat pendidikannya dapat

\begin{tabular}{|l|l|l|l|}
\hline Volume XII & Nomor 02 & September 2011 & ISSN 1411-1829 \\
\hline
\end{tabular}


digolongkan rendah, artinya penguasaan kerja belum sesuai dengan tingkat umur produktif.

Penyerapan lapangan pekerjaan dengan pertumbuhan $1,3 \%$ setiap tahun, dan kondisi kualitas tenaga kerja pada kisaran usia kerja 1524 tahun seperti diuraikan di atas maka beban kebutuhan tenaga kerja dan tingkat produktivitas pekerjaan terhadap peluang penyerapan tenaga kerja menjadi dilema. Hal ini dapat dilihat dengan adanya angka usia kerja yang besar, dan rendahnya kesesuaian kualitas tenaga kerja. Dengan demikian perlu ditunjang oleh penyelarasan pendidikan terhadap perkembangan dunia kerja yang diperlukan.

Besarnya angka usia kerja yang memiliki kesenjangan dalam kualitas sebagai tenaga kerja tersebut secara langsung akan berdampak pada permasalahan kependudukan yang terkait, yakni: (1) Jumlah penduduk yang besar dan seharusnya menjadi modal dasar pembangunan belum berjalan efektif, (2) Struktur masyarakat masih berpola agraris, dan hanya sebagian kecil masyarakat diperkotaan yang mulai berbudaya industri, (3) Masih banyak yang berpikir tradisional dari pada rasional, dan ketidak-mampuan bekerja keras, kurang disiplin, serta (3) kualitas pendidikan secara umum yang masih rendah (BPS/Sakernas., 2007; www.nakertrans.go.id).

Pendekatan (model) perencanaan tenaga kerja (PTK) yang digunakan selama ini Manpower Requirement Approach (MRA) sudah tidak sesuai lagi dengan perkembangan situasi dan kondisi bidang ketenagakerjaan. Mengingat bahwa (1) ada perubahan kondisi perekonomian (akibat krisis multi dimensi); (2) perubahan sistem pemerintahan (desentralisasi otonomi darah); (3) perubahan kebijakan prioritas pembangunan yang ada di daerah kota/kabupaten; dan (4) adanya komitmen pemerintah untuk melaksanakan lapangan kerja yang layak atau Decent Work secara berkesinambungan.

Pemenuhan pasar internasional tentang ketenagakerjaan maupun domestik, sejalan dengan peningkatan kualitas tenaga kerja, etos kerja, penguasaan pengetahuan ruang lingkup kerja, kecerdasasan dalam keterampilan kerja komponen dasar yang memberikan penilaian terhadap kinerja tenaga kerja secara utuh. Salah satu etos kerja yang dapat diukur adalah sikap tenaga kerja yang berwawasan lingkungan dalam proses pelaksanaan pekerjaan.

Perkembangan dunia kerja dewasa ini adanya dampak globalisasi secara luas mengalami tekanan dalam penerapan konsepkonsep pembangunan yang berkelanjutan maka peranan dunia usaha harus mengarahkan pada peningkatan mutu melalui penerapan konsepkonsep lingkungan hidup. Salah satu prasyarat dalam dunia usaha tersebut adalah kemampuan sumber daya manusia dalam menyikapi operasional suatu usaha yang mengutamakan pelestarian lingkungan. Efek utama sikap berwawasan lingkungan akan terjadi kecenderungan usaha dalam meningkatan efektivitas dan eko-efisiensi kerja terutama dalam memanfaatkan sumber daya alam, baik secara langsung maupun secara tidak langsung, dan sekaligus memperkecil dampak lingkungan yang dihasilkan.

Hal ini dikenal dengan pengembangan dunia kerja yang berwawasan lingkungan sebagai efek dari tuntutan masyarakat tentang pengurangan dampak proses kerja terhadap permasalahan lingkungan hidup. Borrow dalam buku Environment Management menyatakan, bahwa keberadaan lembaga korporasi tidak akan terlepas dalam tanggungjawab terhadap kualitas lingkungan hidup sebagai bagian proses produktivitas pada suatu korporasi. Pedoman korporasi dalam pengelolaan lingkungan adalah termasuk pendidikan tenaga kerja untuk peduli terhadap isu-isu lingkungan, perbaikan manajemen yang relevan dengan regulasi lingkungan, kepastian manajemen limbah, dan mengkoreksi kesalahan manajemen pada waktu sebelumnya (Barrow, 2006: 113).

Permasalahan yang timbul akibat perkembangan jumlah penduduk dan banyaknya jumlah pencari kerja serta kurangnya ketersediaan lapangan kerja, maka sebagian dari mereka berinisiatif untuk mencari lapangan kerja di luar negeri. Kebutuhan lapangan pekerjaan di luar negeri dapat meliputi berbagai bidang pekerjaan keahlian seperti kebidanan dan kesehatan, teknisi peralatan mekanik, bengkel, dan tata boga.Oleh sebab itu diperlukan suatu strategi pelatihan praktis yang mampu menjawab kebutuhan dunia kerja yang didukung oleh kapasitas etos kerja dengan sikap terhadap 
pembangunan yang berwawasan lingkungan.Dengan demikian perlu disadari bahwa selain upaya pemenuhan kerja di luar negeri, juga peruntukan kebutuhan tenaga terampil dalam keahlian untuk kebutuhan dalam negeri yang merupakan prioritas untuk dapat dipenuhi.Artinya bahwa upaya peningkatan kualitas tenaga kerja juga untuk memperkecil besarnya permasalahan kependudukan secara umum di Indonesia, terutama dalam mengantisipasi desakan urbanisasi.

Salah satu aspek yang menjadi tolok ukur kualitas tenaga kerja yang selaras dalam pengembangan korporasi tersebut adalah sikap hidup yang berwawasan lingkungan, yaitu pola hidup yang berpihak pada perbaikan kualitas lingkungan hidup. Secara umum sikap berwawasan lingkungan dapat berhubungan dengan pemahaman dan interpretasi terhadap etos kerja berdasarkan tingkat pendidikan baik pendidikan formal maupun non-formal, kualitas agama, dan sosial budaya masyarakatnya. Sikap tersebut dapat meliputi kesadaran manusia akan hakikat kehidupan dan kelangsungan ekosistemnya tergantung dari kondisi lingkungan atau habitatnya. Sebaliknya habitat tergantung pula pada sikap manusia dalam mempengaruhi lingkungan (Resosoedarmo, Soedjiran; Kartawinata, Kuswata; dan Soegiarto, Aprilani; 1985: 143).

Bentuk sikap yang berwawasan lingkungan merupakan pencerminan etos kerja yang mengutamakan pemeliharaan sumbersumber daya kerja yang berkesinambungan dalam pencapaian produktivitas yang berkelanjutan. Sikap berwawasan lingkungan sebagai wacana baru dalam pengembangan kapasitas sumber daya manusia yang memiliki kekuatan dalam menumbuhkan pemahaman terhadap lingkungan yang berkelanjutan. Satusatunya alasan terpenting dari sikap adalah sebagai pedoman untuk berperilaku. Kecenderungan berperilaku yang berwawasan lingkungan berarti dibentuk berdasarkan landasan sikap yang bersumber pada besaran pengetahuan yang diperoleh sesuai dengan pengalamannya (Clifford T. Morgan, Richard A. King, John R. Weisz, John Schopler, 1987: 383).

Pembangunan yang berkelanjut-an diungkapkan pertama kali pada tahun 1984 pada sidang PBB, dan diterbitkannya buku "Our Common Future” sebagai Brundlent Report untuk perhatian terhadap perkembangan dunia masa depan. Dalam report disebutkan bahwa diperlukannya bingkai komitmen politik dalam proses pembangunan manusia dan ketersediaan sumber daya alam yang sesuai pada peruntukan waktunya bagi masa kini dan masa mendatang. Sikap yang berwawasan lingkungan pada kelompok tenaga kerja dibutuhkan dalam membangun perilaku yang konsisten terhadap pengendalian konseksuensi lingkungan sebagai tuntutan pembangunan global. Sikap seseorang seharusnya konsisten dengan perilaku. Seandainya sikap tidak konsisten dengan perilaku, mungkin ada faktor dari luar diri manusia yang membuat sikap dan perilaku tidak konsisten. Faktor tersebut adalah sistem nilai yang berada di masyarakat, di antaranya norma, politik, dan budaya.

Dari penjelasan tersebut jelas bahwa pelatihan pembentukan sikap tenaga kerja yang berwawasan lingkungan bukan semata-mata tanggung jawab lembaga diklat, tetapi seluruh partisipasi masyarakat dan instansi terkait harus menunjang pelaksanaan pendidikan pelatihan. Pendidikan dan pelatihan haruslah diletakkan pada kondisi dan situasi yang benar-benar kondusif bagi jalannya proses pendidikan dan pelatihan. Dengan cara demikianlah, sebenarnya secara teoritis dan konseptual, tujuan pendidikan dan pelatihan dapat tercapai. Sebaliknya, jika masyarakat dan seluruh instansi politik dan pemerintahan tidak menunjang maka pendidikan dan pelatihan akan mengalami kegagalan. Oleh karena itu, pengembangan pendidikan pelatihan merupakan tanggung jawab seluruh warga bangsa, dan harus ditunjang oleh komitmen politis dari seluruh warga bangsa.

Kendala penumbuhan sikap terjadi ketika ada benturan nilai yang diyakini seseorang dengan nilai yang berkembang di masyarakat. Semua institusi dalam masyarakat harus dapat menunjang pendidikan. Artinya, masyarakat secara menyeluruh harus memberikan dukungan terhadap proses pendidikan. Akan tetapi, dalam kenyataannya, di negara yang sedang berkembang seperti Indonesia, pendidikan mungkin mengalami hambatan sosio-budaya, seperti yang dikemukan oleh Jinghan (1999: 33). Todaro ahli 
ekonomi yang mengatakan bahwa kapasitas tenaga kerja di negara sedang berkembang memiliki ciri yang hanya berpikir skala ekonomi tanpa memperlihatkan nilai tambah lainnya terutama wawasan lingkungan hidup.. Sifat inilah yang merupakan kedala bagi kemajuan ekonomi negara dunia ketiga (Todaro, 1997: 89).

Pendidikan dan pelatihan ketenagakerjaan mempertimbangkan kebutuhan akan perubahan sikap yang berwawasan lingkungan, maka diperlukan peraturan dan membentuk kondisi sosial budaya yakni sikap terhadap pelestarian lingkungan hidup. Untuk itu penelitian ini akan melakukan kajian tentang sikap tenaga kerja yang berwawasan lingkungan, melalui analisis beberapa variabel yang baik secara langsung dan tidak langsung mempengaruhi pembentukan etos kerja dan sikap berwawasan lingkungan.

\section{Perumusan Masalah}

Berdasarkan identifikasi masalah dan pembatasan masalah, maka perumusan masalah penelitian ini adalah:

1. Apakah secara keseluruhan terdapat perbedaan sikap tenaga kerja yang berwawasan lingkungan antara yang memperoleh strategi pelatihan kunjungan objek kerja dan strategi pelatihan diskusi kelompok?

2. Apakah terdapat perbedaan sikap tenaga kerja yang berwawasan lingkungan yang memiliki konsep dasar ekologi tinggi antara yang memperoleh strategi pelatihan kunjungan objek kerja dan strategi pelatihan diskusi kelompok?

3. Apakah terdapat perbedaan sikap tenaga kerja yang berwawasan lingkungan yang memiliki konsep dasar ekologi rendah antara yang memperoleh strategi pelatihan kunjungan objek kerja dan strategi pelatihan diskusi kelompok?

4. Apakah terdapat pengaruh interaksi antara strategi pelatihan dan pengetahuan konsep dasar ekologi terhadap sikap tenaga kerja yang berwawasan lingkungan?

\section{KAJIAN TEORETIK DAN PENGAJUAN HIPOTESIS}

1. Sikap Tenaga Kerja yang Berwawasan Lingkungan
Sikap merupakan aspek penting dalam menentukan tindakan seseorang. Mempelajari sikap berarti juga dapat memahami tingkah lakunya. Istilah “sikap” pada hakikatnya merupakan pernyataan yang sederhana tentang seberapa suka atau tidak suka seseorang terhadap sesuatu keaneka-ragaman (Morgan, Clifford T. et al, 1987: p.487). Sikap didefinisikan pula sebagai kapasitas mental berdasarkan pengalaman terkait yang mempengaruhi respon setiap individu terhadap suatu obyek (Oskamp, 1997:9). Menurut Koentjaraningrat, sikap adalah suatu disposisi atau keadaan mental dalam jiwa dan diri sesesorang individu untuk bereaksi terhadap lingkungannya, baik lingkungan sosial, lingkungan alamiah, maupun lingkungan fisiknya.

Hal di atas cukup relevan apabila dibandingkan dengan batasan sikap yang dikemukakan oleh Krech, Crutchfield, dan Ballachey yang menyatakan bahwa sikap adalah kecenderungan seseorang memberikan reaksi dalam bentuk rasa maupun dalam bentuk perbuatan terhadap gejala atau objek yang dihadapinya. Jadi apabila sikap mengarah kepada objek tertentu berarti penyesuaian diri telah terjadi dan timbul kesediaan untuk bertindak (Krech, David., Crutchfield, Richard., and Ballacey, Egerton L., 1962: p. 139).

Ditambahkan oleh Muller yang mengutip Thurstone yang mendefinisi-kan, bahwa sikap adalah yang mempengaruhi seseorang terhadap suatu obyek psikologis (Muller, Daniel J., 1989: p.3). Campbell menguatkan pernyataan di atas, bahwa sikap merupakan penentu bagi manusia dalam melakukan kegiatan yang dinyatakan dalam bentuk tingkah laku ataupun dalam bentuk ucapan, disertai dengan perasaan-perasaan tertentu dalam menanggapi suatu gejala atau objek (Campbell, Donald T., 1967: pp. 175-177). Kisaran teori di atas menunjukan bahwa sikap merupakan suatu sistem yang secara reltif menetap dalam diri individu berupa penilaian yang bersifat positif atau negatif yakni suatu kecenderungan untuk menyetujui atau menolak.

Sikap mempunyai beberapa karakteristik, yaitu sikap itu mempunyai arah, intensitas, keluasaan, konsistensi, dan spontanitas. Arah di sini berarti dapat merupakan arah negatif atau posistif. Intensitas artinya kekuatan sikap,

\section{\begin{tabular}{|l|l|l|l|}
\hline Volume XII & Nomor 02 & September 2011 & ISSN 1411-1829 \\
\hline
\end{tabular}}


keluasan akan menyangkut cakupan aspek objek sikap, dan yang dimaksud konsistensi adalah kesesuaian antara pernyataan sikap dengan responnya terhadap sikap (Krech, David., Crutchfield, Richard., and Ballacey, Egerton L. 1962: p. 155)

Menurut Bloom, sikap dalam kisaran pengertian ranah afeksi mengandung aspek tanggapan atau responding, penilaian (valuing), dan Pengorganisasian (organizing). Aspek responding yakni mengandung makna kemauan untuk melakukan tanggapan dan kepuasan dalam tanggapan. Pada aspek valuing mengandung makna lebih utuh yakni penerimaan nilai, kesesuaian nilai, dan komitmen. Sedangkan pada aspek organization mengandung makna konseptualisasi dari suatu nilai (David $\mathrm{R}$. Krathwohl., Benjamin S. Bloom., Bertram B. Masia, 1972: 37)

Berdasarkan karakteristik di atas, sikap mengandung komponen yaitu (1) cognition atau kognisi dinamakan belief, (2) Affection atau afeksi, (3) behaviour atau konasi disebut dengan intention (Sears, David O., Freedman, Jonatan L. and Peplau, L. Anne., 1992: p.138). Selanjutnya diterangkan bahwa sikap itu merupakan pernyataan evaluatif, baik yang bersifat menyenangkan atau tidak menyenangkan tentang objek, orang, atau kejadian tertentu. Sedangkan
Leonard Berkokitz dalam Holahan, mendefinisikan sikap yaitu menitik beratkan pada bagaimana manusia merasakan mengenai sesuatu dengan perasaan suka atau tidak suka terhadap suatu objek atau peristiwa. (Holahan, Charles J., 1982: p.92)

Komponen-komponen sikap sesuai yang diterangkan oleh Malim dan Birch, bahwa respon terhadap suatu objek, yaitu (1) Respon kognitif, yaitu persepsi tentang sesuatu atau kepercayaan, (2) Respon afektif, yaitu perasaan atau motivasi yang diarahkan terhadap suatu objek, (3) Respon konatif, yaitu respon perilaku yang berkaitan objek atau perhatian kecenderunagn perilaku lainnya (Malim, Tony and Birch, Ann., 1989: p.31). Secara skematis dapat dilihat pada Gambar 1.

Dengan memperhatikan keempat definisi sikap di atas, maka dapat dikatakan bahwa setiap sikap mengandung tiga komponen, yaitu kognisi yang menitikberatkan pada pengertian dan konsep berfikir yang positif atau negatif terhadap suatu obyek, komponen afeksi berupa emosi yakni perasaan senang, atau tidak senang dan komponen konasi berupa kecenderungan untuk berbuat atau bertindak terhadap obyek sosial.

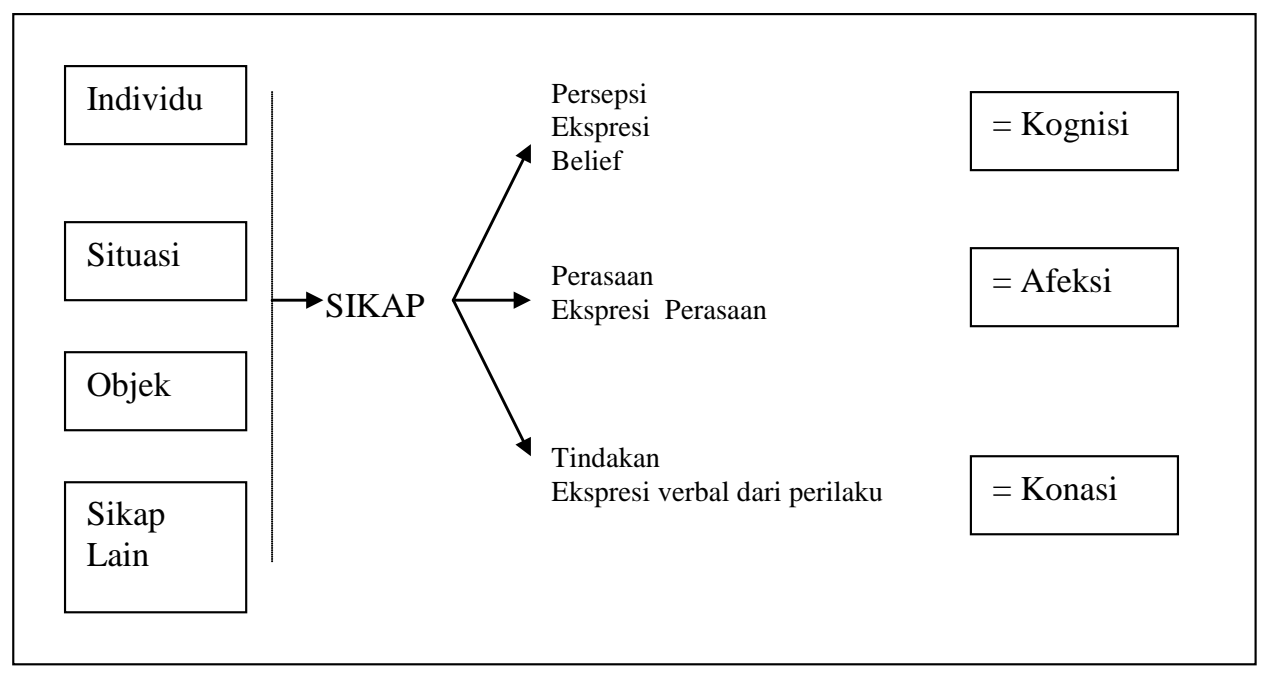

Gambar 1: Skema Konsepsi mengenai Sikap dari Rosenberg dan Hovand (Malim, Tony and Birch, Ann ., 1989: p.31

\begin{tabular}{|l|l|l|l|}
\hline Volume XII & Nomor 02 & September 2011 & ISSN 1411-1829 \\
\hline
\end{tabular}


Uraian di atas akan mengarah bahwa sikap didasari oleh informasi dan merupakan sistem keyakinan yang bertahan cukup lama (enduring system), tentang bagaimana manusia mengevaluasi obyek lingkungannya. Sistem ini terdiri dari tiga komponen yaitu (1) pengertian dan pemahaman (cognition), (2) perasaan (feeling) dan (3) kecenderungan untuk bertindak (action tendency).

Sebagai suatu sistem, ketiga komponen sikap tersebut satu sama lain berhubungan dan saling mempengaruhi. Komponen kognisi megandung persepsi, pengetahuan, kepercayaan, dan cara pandang individu mengenai suatu objek. Komponen afeksi mengandung unsur perasaan atau apa yang dirasakan seseorang tentang suatu objek dan menyangkut masalah emosional. Komponen konasi mengandung tendensi atau kecenderungan bereaksi terhadap sesuatu objek dengan cara-cara tertentu.

Berdasarkan uraian teoretik di atas, maka dapat disintesis bahwa sikap menunjukan adanya tingkat persetujuan yang didasarkan oleh pengetahuan, emosial dalam penilaian, dan kecenderungan dalam bertindak. Untuk itu sikap mempunyai definisi sebagai derajat atau tingkatan perasaan positif-negatif seseorang yang agar tercipta hubungan yang berkelanjutan. Pola dasar mentalitas personal dapat disebut juga sebagai cara pandang atau wawasan individu terhadap lingkungannya.

Wawasan adalah pandangan, tinjauan, penglihatan dan tanggap inderawi (Muller, Daniel J., 1989: p.253). Kuswartojo dan Suparti mengemukakan konsep berwawasan lingkungan adalah pandangan yang tercermin dalam perilaku seseorang yang selalu mengupayakan lingkungan yang serasi antara manusia dan masyarakatnya dengan alam serta berbagai unsur buatan (Kuswartojo, Tjuk dan Salim, Suparti Amir, 1997: p.12).

Cara pandang atau wawasan terhadap lingkungan ini menurut Soemarwoto mempunyai ruang lingkup sebagai berikut; (1) pengelolaan lingkungan secara rutin, (2) perencanaan dini dalam pengelolaan lingkungan, (3) perencanaan lingkungan berdasarkan perkiraan dampak, (4) dan perencanaan pengelolaan berdasarakan kerusakan lingkungan. (Soemarwoto, Otto., 1985: h.82-89). Untuk itu sikap berwawasan lingkungan ditunjukkan oleh tingkat pengetahuan, perasaan untuk melakukan penilaian, dan kecenderungan untuk bertindak terhadap kondisi lingkungan sekitarnya.

Berkaitan dengan konsepsi lingkungan, tendensi seseorang untuk memberikan respon berupa emosi, perasaan, keyakinan, penghargaan, dan kecenderungan bertindak terhadap lingkungan dapat bersifat positif dan negatif. Konsepsi lingkungan tersebut di dalam Chiras secara personalitas dapat disebabkan oleh mental atau dikenal dengan mental frontier, yaitu bahwa manusia adalah bagian dari alam yang berkuasa di atas makhluk lainnya. Ciri mentalitas ini adalah (1) sumber daya tidak ada batasnya, (2) kehidupan akan lebih baik dengan menguasai materi, (3) pembiayaan material mencukupi seluruh kegiatan, dan (4) teknologi mampu mengatasi lingkungan, dan (5) manusia adalah penguasa lingkungan (Chiras, Daniel D., 1991: p. 458).

Pola mentalitas pada setiap personal akan mengarah pada etika terhadap kualitas lingkungan tentang bagaimana manusia seharusnya berinteraksi dengan lingkungan dan dengan sesama manusia

merupakan ciri personalitas individu pada setiap aktivitas berdasarkan ruang lingkup di atas.

Sikap berwawasan lingkungan perlu mendapat perhatian seperti yang dikemukakan oleh Mesarovic dan Pastel bahwa dalam menanam sikap pembangunan yang bijaksana terhadap lingkungan hendaknya mempertimbangkan faktorfaktor sebagai berikut: (1) kesadaran tentang bumi sebagai milik bersama; (2) dikembangkan etika baru dalam pembangunan sumber daya alam; (3) sikap keharmonisan dengan alam; dan (4) manusia harus mengembangkan sikap bertanggungjawab kepada generasi mendatang (Mesarovic, Mihajlo., and Pestel, Edward., 1974: p.147).

Aspek lingkungan hidup tersebut, menurut Sumarwoto adalah jumlah semua benda dan kondisi di dalam ruang yang mempengaruhi kehidupan makhluk hidup (Otto, Sumarwoto, 1999: p. 51). Selanjutnya diterangkan juga, bahwa manusia bersama tumbuhan, hewan dan jasad renik menempati suatu ruang tertentu, di mana di dalamnya terdapat makhluk hidup juga benda tak hidup seperti udara, air, tanah dan batu. Ruang 
yang ditempati suatu makhluk hidup dengan benda hidup dan tak hidup di dalamnya itu disebut lingkungan hidup makhluk tersebut.

Sejalan dengan pernyataan di atas, Soerjani mengatakan lingkungan hidup adalah sistem kehidupan di mana terdapat campur tangan manusia terhadap tatanan ekosistem. (Soerjani, Moh., 1987: h.3). Kemudian diterangkan, bahwa lingkungan hidup di sini terbagi tiga yaitu: (1) lingkungan hidup alam, (2) lingkungan hidup binaan, dan (3) lingkungan hidup sosial yang saling berkaitan dan saling berinteraksi sehingga menentukan kualitas lingkungan hidup.

Lebih konkrit lagi oleh Chiras dalam bukunya Environmental Science mengatakan seorang biolog membagi lingkungan menjadi dua bagian yaitu abiotik (komponen tidak hidup) dan biotik (komponen hidup). Selanjutnya Chiras menerangkan bahwa permasalahan lingkungan dapat meliputi aspek-aspek yang menjadi indikator menurunnya kualitas sumber daya kehidupan pada kegiatan masa lalu, saat ini, dan prospek bagi kebutuhan di masa datang. Aspek permasalahan lingkungan tersebut adalah pencemaran dan limbah, energi, degradasi lahan, keanekaragaman hayati, sumberdaya air (Chiras, 1987: 116).

Nebel menyatakan, bahwa aspek lingkungan terbagai dalam tiga komponen besar yaitu komponen makhluk hidup atau biotik, komponen makhluk tak hidup atau abiotik), dan komponen kombinasi antara keduanya berupa interaksi serta faktor-faktor pendukungnya (Nebel, Bernard ,J. and Wright, Richard. T., 2000: p. 47)

Wawasan adalah pandangan, tinjauan, penglihatan dan tanggap inderawi (Soerjani, Moh., 1987: h.253). Orang yang memiliki tanggap inderawi maksudnya mempunyai rasa kepedulian terhadap peristiwa - peristiwa yang terjadi di sekitarnya yang terlihat melalui panca indera, dan akan melahirkan rasa tanggung jawab untuk mengatasinya. Pandangan manusia mengenai alam terdiri dari dua tahap yaitu manusia tunduk pada alam (tahap pan cosmism) dan manusia menguasai serta mengeksploitasi sumber daya alam dengan tidak terbatas(tahap anthropocentries) (Hadi, Sudharto P.1998: h. 17-29). Pada tahap pan cosmism, manusia memandang alam sebagai sesuatu yang harus di jaga keserasian dan kelestariannya.
Pada tahap anthropocentries manusia memandang bahwa mereka merasa menguasai alam dimana manusia tidak lagi hanya memanfaatkan alam sebagai kebutuhan primer tetapi juga memanfaatkan alam untuk kebutuhan keindahan, kebanggaan dan prestise. Tahapan yang dicita-citakan dan diharapkan, yaitu suatu tahapan dimana manusia berpandangan perlunya menyelaraskan kehidupan dan aktivitas dengan alam. Dalam mendayagunakan alam, manusia di harapkan selalu memperhatikan daya dukungnya sehingga keberlanjutan aktivitas manusia tetap bisa berlangsung.

Tahapan ini disebut dengan paham holism, yaitu manusia hendaknya berpikir dialektis dalam arti bahwa kerusakan alam senantiasa berhubungan dengan ulah manusia. Kekayaan alam dan kelestarian daya dukungnya selalu berhubungan dengan tanggung jawab dan kesadaran ekologis manusia. Manusia adalah bagian dari lingkungan hidupnya bukan terpisah dari padanya.

Dalam kehidupan manusia harus memiliki wawasan agar mempunyai landasan dalam setiap tindakan atau kegiatan hidupnya. Pendekatan psikologi ekologi (Ecological Psychology) memandang hubungan antara lingkungan dan perilaku seperti jalan dua arah atau dengan perkataan lain sebagai saling ketergantungan ekologi (Bell, Paull A. et al., 1996: p.139).

Dari berbagai uraian di atas dapat disintesis bahwa sikap berwawasan lingkungan adalah derajat atau tingkatan persetujuan yang ditunjukan oleh pengetahuan, emosional dalam melakukan penilaian, dan kecenderungan untuk bertindak berdasarkan cara pandang terhadap permasalahan sumber daya kehidupan yang berkaitan dengan segala aktivitas manusia dan realitas alam di sekitarnya. Dalam kaitan ini aspek-aspek permasalahan sumber daya kehidupan yang berhubungan dengan aktivitas manusia dan realitas alam di sekitarnya dapat terdiri dari aspek pencemaran, limbah dan sampah, energi, air, keanekaragaman hayati, kesatuan lahan, dan kesehatan.

\section{Strategi Pelatihan}

Pengertian strategi menurut Sjafri Mangkuprawira adalah cara mengerjakan sesuatu untuk mencapai tujuan tertentu. Ia merupakan

\begin{tabular}{|l|l|l|l|}
\hline Volume XII & Nomor 02 & September 2011 & ISSN 1411-1829 \\
\hline
\end{tabular}


sebuah rencana permanen untuk sebuah kegiatan. Di dalamnya biasanya termasuk formulasi tujuan dan kumpulan rencana kegiatan. (Mangkuprawira, Sjafri., 2002: p.13).

Pengertian lainnya dari strategi seperti yang disampaikan oleh Child, strategi adalah sekumpulan pilihan dasar atau kritis mengenai tujuan dan cara dari bisnis (Child, J. 6 (3), p.1-22). Pengertian pendidikan dan pelatihan (diklat) menurut Heidjrachman Ranupandojo dan Suad Husnan adalah sebagai suatu kegiatan untuk memperbaiki kemampuan kerja seseorang dalam kaitannya dengan aktivitas ekonomi.Berdasarkan pengertian ini, berarti pelatihan lebih diarahkan untuk melakukan perbaikan (improvement) terhadap kinerja karyawan terutama berkaitan dengan aktivitas ekonomi (Ranupandojojo, Heidjrachman dan Husnan, Suad., 1990: p.43).

Ivancevich dalam Ruky mendefinisikan pelatihan sebagai usaha untuk meningkatkan pekerjaannya sekarang atau dalam pekerjaan lain yang akan dijabatnya segera (Rukky, Achmad S., 2003: h.36). Sementara itu Alex S. Nitisemito lebih menekankan pada aspek pengembangan sikap, tingkah laku, dan keterampilan, seperti yang tampak dalam definisinya: (Nitisemito, Alex S, 1996: p.86)

\section{"Pelatihan adalah suatu kegiatan dari perusahaan yang bermaksud untuk memperbaiki dan memperkembang-kan sikap, tingkah laku, keterampilan dan pengetahuan dari para karyawan-nya, sesuai dengan keinginan dari perusahaan yang bersangkutan."}

Berdasarkan pengertian-penger-tian dari berbagai penulis tersebut dapat disimpulkan bahwa pengertian pelatihan merupakan suatu usaha atau upaya per-baikan dan peningkatan pegawai yang dilakukan oleh perusahaan guna men-dapatkan peningkatan keterampilan pegawai dalam menjalankan beban tugas dari perusahaan sehingga sesuai dengan tujuan dan misi perusahaan.

Pelatihan juga termasuk aktivitas belajar yaitu suatu proses perubahan pada diri seseorang, bedanya dengan pendidikan adalah terjadinya perubahan pengetahuan, pemahaman, keterampilan, sikap dan perilaku yang lebih ditekankan pada tindakan. Sedangkan pendidikan cenderung pada memperbaiki potensi individu untuk berkembang menjadi pribadi yang khas dan utuh (Tilaar, H.A., 1992: h. 24).Selanjutnya H. A. R. Tilaar membedakan ciri-ciri pendi-dikan dan latihan seperti dalam diagram berikut:

\begin{tabular}{|c|c|c|}
\hline $\begin{array}{c}\text { Jenis dan } \\
\text { ciri-ciri }\end{array}$ & Pendidikan & Pelatihan \\
\hline $\begin{array}{c}\text { Modalitas } \\
\text { Kelembagaan }\end{array}$ & Formal Akademis & Praktis \\
\hline $\begin{array}{c}\text { Orientasi } \\
\text { Kelembagaan }\end{array}$ & $\begin{array}{c}\text { Pengembangan } \\
\text { Pribadi }\end{array}$ & $\begin{array}{c}\text { Dunia } \\
\text { Kerja }\end{array}$ \\
\hline $\begin{array}{c}\text { Dimensi } \\
\text { Pengembangan }\end{array}$ & Ideografik & Nomotetik \\
\hline
\end{tabular}

Sejalan dengan hal di atas, Westerman dan Doghune (Westerman, John dan Doughune, Pauline., 1992: h.56) mendefinisikan pelatihan sebagai pengembangan secara sistematis pada, sikap, pengetahuan, dan keterampilan yang diperlukan seorang pekerja untuk melaksanakan tugas dan pekerjaannya secara mandiri.

Uraian di atas menunjukan bahwa setiap pelatihan pada hakikatnya merupakan suatu proses belajar meng-ajar, sehingga inti teori latihan adalah teori belajar. Program latihan menunjuk-an penerapan teori belajar yaitu tindakan yang dianggap efektif untuk membantu individu dalam belajar. Berdasarkan hal tersebut maka penerapan strategi pela-tihan juga menggunakan startegi pembe-lajaran, namun lebih mempertimbangkan pada keterampilan tindakan.

Bernandin dan Russell dalam Gomes mengelompokkan ke dalam dua kategori disain pelatihan (Gomes, Faustino Cardoso., 2000: p.207), yaitu:

(1). Informational Methods, yaitu strategi dengan menggunakan pendekatan satu arah, dimana informasi-informasi disam-paikan kepada para peserta oleh para pelatih. Strategi ini dipakai untuk meng-ajarkan hal-hal faktual, keterampilan atau sikap tertentu;

(2). Experiental Methods, yaitu strategi yang mengutamakan komunikasi yang luwes, fleksible, dan lebih dinamis, baik dengan instruktur, dengan sesama pe-serta, dan langsung menggunakan alatalat yang tersedia, misalnya komputer.

Menurut Gomes Supaya efektif, pelatihan harus merupakan suatu solusi yang tepat bagi permasalahan organisasi, yakni bahwa pelatihan tersebut harus dimaksudkan untuk

\section{\begin{tabular}{|l|l|l|l|}
\hline Volume XII & Nomor 02 & September 2011 & ISSN 1411-1829 \\
\hline
\end{tabular}}


memperbaiki kekurangan ketrampilan. Program pela-tihan dapat dievaluasi berdasarkan informasi yang bisa diperoleh pada lima tingkatan, yaitu:

(1). Reactions, ukuran ini didisain untuk mengetahui reaksi peserta pelatihan pada akhir pelaksanaan pelatihan dengan menggunakan kuesioner;

(2). Learning, ukuran ini didisain untuk mengetahui seberapa jauh peserta menguasi konsep, pengetahuan dan keterampilan yang diberikan melalui test tertulis;

(3). Behaviors, melihat perilaku peserta sebelum dan sesudah mengikuti pelatih-an, evaluasi dilakukan oleh para super-visor setelah mengikuti pelatihan;

(4). Organizational Result, melihat dampak pelatihan terhadap kelompok kerja atau organisasi secara keseluruh-an. Informasi dapat dikumpulkan sebe-lum dan sesudah pelatihan dengan meilihat absensi, perbaikan kualitas, kepuasan pelanggan;

(5). Costs Effectivity, untuk mengetahui seberapa besar biaya yang dihabiskan bagi program pelatihan yang dibanding-kan dengan biaya yang timbul dari permasalahan organisasi

Berdasarkan uraian tersebut di atas dapat disintesis bahwa strategi pelatihan adalah suatu cara yang digunakan dalam kegiatan proses pelatihan untuk pencapaian perubahan skap yang menitikberatkan pada perubahan sikap sesuai dengan tuntutan perkembangan dunia kerja, yaitu sikap berwawasan lingkungan.

\subsection{Strategi Pelatihan Kunjungan Objek Kerja}

Kunjungan objek kerja adalah suatu perjalanan yang dikelola dan disesuaikan dengan sasaran pembelajar-an untuk mengajak pembelajar mengun-jungi tempat dimana material-material pengajaran dapat secara langsung tera-mati dalam pengelolaan kawasan secara fungsionalnya (Jones, Anthony S., Bagford, Lawrence W., and Wallen, Edward A.., 1979:p. 56). Sebagai suatu strategi pembelajaran aktif, bentuk kunjungan objek kerja mempunyai potensi untuk meningkatkan upaya peserta didik dalam belajar sesuai tingkat pengetahuan yang diperoleh di kelas dengan realitas pengalaman yang sebenarnya (Powis, Kelli., 1999: http//www.uotawa.ca/academic/cut/options/Feb_9 9/Fieldtrip_en.htm)
Sedangkan apabila dipandang dari teori Cone of Learning (Edgar Dale), kategori kunjungan objek kerjamempunyai makna yang serupa dengan kegiatan karya wisata atau perjalanan/kunjungan lapangan (Field Trip) digolongkan ke dalam fase pertama dalam proses berpartisipasi secara aktif, sedangkan fase awal didahului oleh penerimaan pasif melalui verbal, symbol, audio-visual, dan kunjungan lapangan sebagai fase terakhir dari tahap penerimaan visual dari keterlibatan secara pasif (Anon., 2006: www.compstrategies.com) Hal ini berarti keberhasilan strategi karya wisata sangat ditentukan pola pembelajarannya apakah akan dilakukan secara aktif atau dilakukan secara pasif. Strategi belajar aktif merlalui kegiatan kunjungan objek kerja akan mendorong peserta didik untuk terlibat dalam pembelajaran berdasarkan pengalamannya.

\subsection{Strategi Pelatihan Diskusi Kelompok}

Model belajar Kelompok termasuk salah satu bentuk strategi pembelajaran Cooperative Learning, sedangkan Cooperative Learning adalah satu satu strategi belajar dalam pendekatan belajar secara Inkuiri. Pembelajaran kooperatif sebenarnya gabungan banyak jenis bentuk penga-jaran dan pembelajaran. Polanya dengan menggiatkan tenaga kerja belajar bersamasama melalui pembentukan kelompok yang homogen. Pembelajaran koopeatif dilaksanakan secara kelompok kecil supaya tenaga kerja dapat berkerjasama untuk mempelajari isi kandungan pelajaran dengan berbagai interaksi sosialnya. Secara dasarnya, pembelajaran kooperatif melibatkan pelajar bekerjasama dalam mencapai salah satu objektif pembelajaran (Johnson, d.W.,\& Johnson, 1991: p.216)

Pada strategi ini, Cooperative learning dapat dikatakan sebagai sistem kerja atau belajar kelompok yang terstruktur. Di dalam konsep ini terdapat 5(lima) unsur pokok yaitu saling ketergantungan, tanggungjawab indivi-dual, interaksi antara pembelajar, dan keterampilan dalam bekerja sama dan proses dinamika kelompok (Lie, Anita., 2002: p. 71). Ciri-ciri pembelajaran ini adalah 1) menentukan aspek pembela-jaran yang akan dikaji; 2) menitikberatkan pada mekanisme interaksi sosial; 3) Saling ketergantungan anatra tenaga kerja dalam

\begin{tabular}{|l|l|l|l|}
\hline Volume XII & Nomor 02 & September 2011 & ISSN 1411-1829 \\
\hline
\end{tabular}


penggalian kajian secara dinamis. Hal ini memberikan manfaat bahwa melalui pembelajaran kooperatif akan membaiki hubungan sosial, meningkatkan penca-paian belajar, kemampuan kepemimpin-an, hubungan sosial, teknologi, dan rasa percaya dan keyakinan.

Konsep dasar diskusi kelom-pok menurut Thelen yang dikutip oleh Bruce Joyce dan Marsha Weil meliputi tiga hal yaitu Inkuiri, Pengetahuan dan Dinamika kelompok belajar (Anita Lie, 2002: p.232-236).Dinamika kelompok dalam kegiatan pembelajaran adalah suatu bentuk interaksi sosial antara individu yang berkembang berdasarkan perubahan unsur kepribadian individual menjadi wujud kepribadian kelompok sebagai satu kesatuan organisasi dalam melakukan pembelajaran yang sistematik.

Pola pembelajaran Inkuiri merupakan salah satu proses sosial siswa dalam observasi mereka sendiri. Pengetahuan sebagai tujuan dari investigasi yang mencapai ruang lingkup aplikasi dari prinsip yang diperdebatkan dari masa lampau untuk pengalaman-pengalaman masa sekarang. Dinamika kelompok belajar idealnya terdiri atas 10 sampai 15 siswa yang mengarah kepada keaktifan kelompok secara produktif. Sehingga cenderung kelompok belajar menjadi dinamis.

\section{Pengetahuan Tentang Konsep Dasar Ekologi}

Pengetahuan pada hakikatnya merupakan segenap apa yang diketahui manusia tentang suatu obyek tertentu. Ilmu termasuk ke dalam pengetahuan. Pengetahuan dikumpulkan oleh ilmu dengan tujuan untuk menjawab perma-salahan kehidupan yang sehari-hari dihadapi manusia, dan digunakan dalam menawarkan berbagai kemudahaan kepadanya (Suriasumantri, Jujun S., 1998: p.32).

Aspek pengetahuan diklasifikasi-kan ke dalam tiga kelompok, yakni (1) pengetahuan mengenai hal-hal yang bersifat khusus meliputi istilah dan fakta; (2) pengetahuan tentang cara untuk menangani masalah-masalah khusus meliputi: kebiasaan, kecenderungan, klasifikasi, kategori dan strategi; dan (3) pengetahuan tentang kaidah yang bersifat universal meliputi: prinsip, teori dan struktur (Bloom, Bunjamin S, 1954: p.89).
Pengetahuan menurut Revisi dari Bloom terbagi menjadi empat tipe pengetahuan yaitu: (1) factual (berdasar-kan fakta-fakta sesungguhnya), (2) Conseptual (berkaitan dengan konsepsi/pengertian), (3) Procedural (berkaitan dengan pelaksanaannya), (4) Metacognitive. (Anderson, Orin W. and Krathwohl, David R., 2001: p. 27).

Pengetahuan factual mempunyai ciri pengetahuan yang tersendiri, kandungan element tersendiri-bagian kecil dari informasi yang harus diketahui oleh tenaga kerja untuk memecahkan masalah termasuk: (1) pengetahuan terminologi (berkaitan dengan istilah), dan (2) pengetahuan yang lebih spesifik dan dasar.

Sebaliknya pengetahuan kon-septual adalah pengetahuan yang lebih kompleks dan terorganisasi, termasuk: (1) pengetahuan dari klasifikasi dan kategori, (2) pengetahuan dari prinsip dan generalisasi, dan (3) pengetahuan dari teori, model dan struktur.

Pengetahuan Prosedural adalah pengetahuan tentang bagaimana mengerjakan sesuatu, termasuk: (1) pengetahuan pokok tentang keahlian khusus dan algoritma, (2) pengetahuan pokok tentang teknik khusus dan strategi, dan (3) pengetahuan tentang kriteria yang digunakan untuk menetapkan dan atau mempertimbang-kan kapan mengerjakan sesuatu dalam domain khusus dan disiplin.

Pengetahuan Metacognitive adalah pengetahuan tentang kognisi secara umum seperti kepedulian dan pengetahuan tentang diri sendiri, meliputi: (1) pengetahuan strategi, (2) pengetahuan tentang tugas kognitif termasuk konsepsi/definisi yang tepat dan pengetahuan kondisional/ bersyarat, (3) Pengetahuan sendiri (Russel Veitch, dan Daniel Arkkelin, 1995:p. 8788).

Veitch dan Arkkelin dalam Environmental Psychology berpendapat, manusia selalu berproses dan berpikir tentang lingkungannya, dan setiap manusia mempunyai pengetahuan yang berbeda-beda tentang alam dan sekitarnya.

Dari uraian teori diatas maka pengetahuan adalah segala sesuatu yang diketahui seseorang mengenai istilah, spesifikasi, klasifikasi dan kategori, prinsip dan generalisasi, teori dan model dan struktur, keahlian khusus dan

\section{\begin{tabular}{|l|l|l|l|}
\hline Volume XII & Nomor 02 & September 2011 & ISSN 1411-1829 \\
\hline
\end{tabular}}


algoritma, teknik khusus dan strategi, kriteria, strategi, definisi dan kondisional serta pengetahuan diri sendiri.

Pengetahuan juga tergantung daripada persepsi seseorang tentang setuju/tidak setuju terhadap sesuatu pendapat, oleh karena itu: (1) tidak lebih daripada pendapat yang dimiliki, (2) tidak lebih daripada yang kita rasakan terhadap persetujuan mereka atau tidak, tergantung daripada persepsi yang merupakan : intuisi, alasan atau sensasi, (3) secara intuisi pengetahuan meluas dengan sendirinya dan tidak terhadap keseluruhan pendapat kita, (4) ilmu tidak untuk dipamerkan, dan (5) kepekaan pengetahuan lebih sempit daripada yang lainnya (Elmer Sprague, Paul W. Taylor, 1959: p.84).

Pengetahuan yang berkaitan dengan konsep dasar ekologi merupakan bentuk operasional dari dimensi-dimensi tersebut. Konsep dasar ekologi terdiri atas sebuah konsep yang mempunyai pengertian sebagai satuan yang mempunyai ciri istimewa serta dapat dikelompokkan atas karakteristik kepunyaan bersama.

Pengertian konsep menurut Bruner, Goodnew dan Austin seperti yang dikutip oleh Sudjana mengatakan unsur-unsur yang terdapat dalam konsep meliputi dua hal yaitu : (1) tinjauan psikologis, konsep itu mengandung hal-hal yang bersamaan, tersusun dan tergabung dalam suatu objek ; (2) konsep memuat hubungan komponenkomponen dalam suatu proses atau kejadian.

Dari rangkaian teori tentang cakupan aspek konsep dasar ekologi di atas, maka dalam menguasai konsep dasar ekologi tersebut terdapat aspek penting yaitu sebagai berikut, (1) hukum energi dan aplikasinya serta efisiensi dan efektifitas penggunaannya, (2) produktivitas, tentang keluaran dari komponen-komponen penyusun kehidupan, (3) rantai makanan, tentang tingkat hirarkis makhluk hidup berdasarkan proses makan dan dimakan, (4) populasi, tentang dinamika penyebaran dan komposisi jenis-jenis makhluk hidup.

Pengetahuan ekologi adalah pokok atau konsep yang mendasar mengenai hubungan timbal balik mahluk hidup dengan lingkungan hidupnya, termasuk di dalamnya menentukan distribusi organisme. Konsep dasar ekologi juga di artikan sebagai ilmu yang mempelajari secara mendasar mengenai seluk beluk rumah tangga (oikos) makhluk hidup yang merupakan sistem dan terdiri atas kesatuan ruang dengan semua benda, energi, tatanan alam serta semua jenis makhluk hidup yang melangsungkan kehidupan dalam sistem.

Odum dalam bukunya Basic Ecology menyatakan bahwa ekologi sebagai bentuk ilmu kerumah-tanggaan alam akan terdiri dari konsepkonsep tentang ekosistem, energi, siklus biogeokimia, faktor-faktor pembatas, populasi, dan evolusi (Odum, Eugene., 1971: pp 1-11).

Komponen-kompnen yang ada di dalam konsep dasar ekologi meliputi pengertian dari ekologi, tipe-tipe ekosistem, daur biogeokimia, proses suksesi, aksi interaksi serta permasalahan lingkungan hidup. Berdasarkan uraian di atas maka yang dikatakan dengan pengetahuan terhadap konsep dasar ekologi meliputi pemahaman pada prinsip-prinsip ekologi seperti tersebut di atas.

Berdasarkan uraian di atas maka yang dimaksud dengan Pengetahuan tenaga kerja tentang konsep dasar ekologi adalah Pengetahuan Konsep dasar ekologi adalah tingkat faktual, konseptual, dan Prosedural dasar tentang seluk beluk rumah tangga (oikos) makhluk hidup yang merupakan sistem dan terdiri atas kesatuan ruang dengan semua benda, energi, tatanan alam serta semua jenis makhluk hidup yang melangsungkan kehidupan dalam sistem.

\section{Kerangka Berpikir}

1. Perbedaan sikap tenaga kerja yang berwawasan lingkungan antara yang memperoleh strategi pelatihan kunjungan objek kerja dan diskusi kelompok.

Strategi pelatihan melalui kegiatan kunjungan objek kerja merupakan proses pelatihan yang berbasis pencapaian keterampilan dengan berinteraksi secara langsung dengan obyek-obyek yang berkaitan erat dengan penguatan wawasan lingkungan. Kegiatan ini akan menjadi proses pengalaman dengan realitas situasi dan kondisi yang sebenarnya, sekaligus mengungkapkan aspekaspek penge-tahuan dan mewujudkan keterikatan emosional. Sedangkan pada strategi pelatihan diskusi kelompok, cenderung akan melakukan pelatihan secara abstrak dengan mengandalkan dinamika

\section{\begin{tabular}{|l|l|l|l|}
\hline Volume XII & Nomor 02 & September 2011 & ISSN 1411-1829 \\
\hline
\end{tabular}}


kelompok dalam membahas aspek-aspek permasalahan lingkungan.

Peserta pelatihan tenaga kerja yang sudah memiliki kecenderungan untuk menerapkan keterampilan tentu saja akan memepunyai pola berpikir yang praktis sesuai dengan tingkatan kebutuhan dan relevansi sosialnya. Pada kegiatan pelatihan dengan strategi kunjungan objek kerja, para tenaga kerja telah mampu mengkondisikan dirinya pada objek-objek konkrit, baik yang dihadapi dalam meknisme pelatihan mapun dengan sasaran keterampilan yang diharapkan pada saat masuk dalam dunia kerja yang sebenarnya.

Sedangkan para tenaga kerja yang mengikuti strategi pelatihan diskusi kelompok akan banyak menghadapi kendala kondisi formal dalam mekanisme interaksi sosial dan interpretasi subject pelatihan yang bersifat penalaran abstrak. Hal ini disebabkan kesiapan kondisi mental yang tidak sejalan dengan sasaran utama pelatihan yang akan berorientasi pada mekanisme kecakapan dan keterampilan kerja yang praktis.

Gambaran tersebut di atas, menunjukan dugaan bahwa strategi pelatihan kunjungan objek kerja akan menimbulkan sikap tenaga kerja yang berwawasan lingkungan lebih baik dibandingkan dengan penerapan strategi pelatihan diskusi kelompok.

2. Perbedaan sikap tenaga kerja yang berwawasan lingkungan yang memiliki pengetahuan konsep dasar ekologi tinggi antara yang memperoleh strategi pelatihan kunjungan objek kerja dan diskusi kelompok

Konsep wawasan lingkungan secara ilmu akan berlandaskan pengetahuan konsep dasar ekologi pada peserta pelatihan. Pengetahuan konsep dasar ekologi pada peserta pelatihan sebenarnya telah diperoleh pada saat mereka masih mengikuti pendidikan formal di Sekolah Lanjutan Atas. Namun seberapa besar penguasaan pengetahuan konsep dasar ekologi akan sangat ditentukan oleh intensitas bacaan mereka yang pernah di alami pada pendidikan formal tersebut.

Pada tenaga kerja yang memiliki pengetahuan konsep dasar ekologi tinggi tentunya akan lebih memiliki kecenderungan bersikap yang lebih baik pada lingkungan. Namun dengan penerapan dua strategi pelatihan yakni strategi kunjungan objek kerja dan diskusi kelompok, pada tenaga kerja dengan pengetahuan konsep dasar ekologi tinggi akan lebih baik dalam percepatan untuk terbentuknya sikap tenaga kerja yang berwawasan lingkungan.

Penerapan strategi pelatihan apabila dibandingkan antara kelompok peserta pelatihan, yakni kelompok yang mempunyai tingkat pengetahuan konsep ekologi tinggi dan kelompok yang mempunyai tingkat pengetahuan konsep ekologi rendah akan cenderung adanya perbedaan dalam sikap yang berwawasan lingkungan. Peserta dengan pengetahuan konsep ekologi tinggi dalam penerapan secara konkrit di lapangan akan cepat merespon positif.

Tingkat pengetahuan tenaga kerja tentang konsep dasar ekologi yang diperoleh pada masa studi di Sekolah Lanjutan Atas merupakan suatu kerangka dasar pada efektivitas penerapan stratgei pelatihan.Seluruh tenaga kerja tentunya mempunyai tingkat pengetahuan tentang konsep dasar ekologi yang berbeda tergantung pada penguasaan materi selama studi di SLTA dan juga lamanya kelulusan yang telah dialaminya.

Kemampuan respon yang cepat tersebut didasarkan bahwa pengetahuan abstraksi tentang ekologi telah dibuktikan dengan pengalaman konkrit di lapangan.Hal ini berbeda apabila dilakukan strategi pelatihan diskusi kelompok, yakni peserta kelompok ini tidak menemukan realitas permasalahan yang sebenarnya secara emosional. Sehingga sikap berwawasan lingkungan pada kelompok peserta dengan pengetahuan konsep ekologi tinggi pada strategi pelatihan kunjungan objek kerja akan lebih baik dibandingkan pelatihan dengan diskusi kelompok.

3. Perbedaan sikap tenaga kerja yang berwawasan lingkungan yang memiliki pengetahuan konsep dasar ekologi rendah antara yang memperoleh strategi pelatihan kunjungan objek kerja dan diskusi kelompok

\section{\begin{tabular}{|l|l|l|l|}
\hline Volume XII & Nomor 02 & September 2011 & ISSN 1411-1829 \\
\hline
\end{tabular}}


Penerapan strategi pelatihan kelompok peserta pelatihan, yakni kelompok yang mempunyai tingkat pengetahuan konsep ekologi rendah dengan penerapan strategi pelatihan kunjungan objek kerja dan diskusi kelompok mempunyai perbedaan dalam tanggapannya. Kelompok ini akan mempunyai kecenderungan lebih baik dalam sikap yang berwawasan lingkungan melalui strategi pelatihan diskusi kelompok.

Hal tersebut disebabkan pada peserta dengan tingkat pengetahuan suatu obyek permasalahan yang masih rendah, tetapi mengalami pola diskusi kelompok yang dinamis, maka akan menimbulkan ketertarikan peserta untuk mengekspresikan hasil pelatihan. Sehingga sikap berwawasan lingkungan pada kelompok peserta dengan pengetahuan konsep ekologi rendah pada strategi pelatihan diskusi kelompok akan lebih baik dibandingkan pelatihan dengan kunjungan objek kerja.

Tenaga kerja dengan pengetahuan konsep dasar ekologi yang lebih rendah memiliki intensitas yang lemah terhadap kemampuan abstraksi tentang konsep ekologi.Namun apabila dibandingkan dengan penerapan startegi pelatihan kunjungan objek kerja dan diskusi kelompok, Maka kelompok ini mampu berusaha membangun konsepsi yang lebih baik dalam mencoba menangkap kandungan dalam permasalahanpermasalahan lingkungan yang sebenarnya belum menjadi pemikiran utamanya.

Hal inilah yang memberikan kecenderungan bgahwa pada kelompok tenaga kerja dengan pengetahuan konsep dasar ekologi rendah akan lebih baik dalam merespon startegi pelatihan diskusi kelompok untuk tercapainya sikap tenaga kerja yang berwawasan lingkungan

4. Pengaruh interaksi antara faktor strategi pelatihan dengan pengetahuan konsep dasar ekologi terhadap sikap tenaga kerja yang berwawasan lingkungan.

Faktor strategi pelatihan dan faktor pengetahuan konsep dasar ekologi merupakan faktor yang saling mempengaruhi dalam menumbuhkan sikap berwawasan
lingkungan.Sikap berwawasan lingkungan sangat dipengaruhi oleh konsep dasar pengetahuan ekologi sebagai konsep terapan dalam perilaku untuk pemeliharaan lingkungan.Sedangkan faktor strategi pelatihan merupakan upaya dalam penyelarasan pada tingkat pelatihan kognitif dan afektif untuk pencapaian keterampilan yang optimal. Berdasarkan hal di atas kedua faktor tersebut akan berinteraksi secara positif.

Adanya interaksi antara strategi pelatihan dan pengetahuan konsep dasar ekologi didasarkan oleh makna pelatihan sebagai proses pelatihan dan keterampilan praktis dengan mengutamakan kemampuan psiko-motorik. Sedangkan aspek pengetahuan konsep dasar ekologis adalah landasan dasar bagai para tenaga kerja dalam menentukan orientasi perilaku sebagai wujud praktis psikomotorik.Oreientasi perilaku tersebut adalah terbentuknya sikap yang mengarah pada intensitas pada terbentuknya perilaku yang berwawasan lingkungan.Dalam konteks ini dapat disebutkan bahwa tingkat pengetahuan konsep dasar ekologi perlu dipertimbangkan sebagai pemicu untuk ketercapaian sikap tenaga kerja yang berwawasan lingkungan dalam mekanisme pelatihan keterampilan tenaga kerja.

\section{Hipotesis}

1. Terdapat perbedaan sikap tenaga kerja yang berwawasan lingkungan antara yang memperoleh strategi pelatihan kunjungan objek kerja dan strategi pelatihan diskusi kelompok.

2. Terdapat perbedaan sikap tenaga kerja yang berwawasan lingkungan yang memiliki konsep dasar ekologi tinggi antara yang memperoleh strategi pelatihan kunjungan objek kerja dan strategi pelatihan diskusi kelompok.

3. Terdapat perbedaan sikap tenaga kerja yang berwawasan lingkungan yang memiliki konsep dasar ekologi rendah antara yang memperoleh strategi pelatihan kunjungan objek kerja dan strategi pelatihan diskusi kelompok.

\section{\begin{tabular}{|l|l|l|l|}
\hline Volume XII & Nomor 02 & September 2011 & ISSN 1411-1829 \\
\hline
\end{tabular}}


4. Terdapat pengaruh interaksi antara strategi pelatihan dan pengetahuan konsep dasar ekologi terhadap sikap tenaga kerja yang berwawasan lingkungan

\section{METODOLOGI PENELITIAN}

Penelitian ini menggunakan desain eksperimen faktorial 2x2, yakni tenaga kerja dibagi ke dalam dua kelompok yang berbeda perlakuannya (perlakukan strategi penyuluhan di dalam kelas dalm bentuk diskusi kelompok dan perlakukan strategi penyuluhan di luar kelas dalam bentuk kunjungan objek kerja).Masing-masing kelompok terdiri atas 30 peserta. Sebelumnya seluruh peserta pelatihan akan dilakukan pengukuran variabel tingkat pengetahu-an dasar ekologi untuk mengetahui tinggi-rendahnya, sehingga masing-masing kelompok akan terdiri dari sub-kelompok yang memiliki tingkat pengetahuan dasar ekologi tinggi dan rendah.

Strategi penelitian eksperimen faktorial selain dapat melihat pengaruh dari salah satu faktor terhadap variabel Y, juga dapat memberikan ada atau tidaknya interaksi antar variabel bebas $\mathrm{X}$ (faktor A dan faktor B) terhadap variabel $\mathrm{Y}$. Desain eksperimen seperti pada Gambar 2.

\begin{tabular}{|c|c|c|c|}
\hline \multicolumn{2}{|c|}{ Variabel Perlakuan } & \multicolumn{2}{|c|}{$\begin{array}{r}\text { STRATEGI PELATIHAN } \\
\text { (A) }\end{array}$} \\
\cline { 2 - 3 } & $\begin{array}{c}\text { Kunjungan } \\
\text { Objek Kerja } \\
\text { (A1) }\end{array}$ & $\begin{array}{c}\text { Diskusi } \\
\text { Kelompok } \\
\text { (A2) }\end{array}$ \\
$\begin{array}{c}\text { PENGE- } \\
\text { TAHUAN } \\
\text { KONSEP } \\
\text { DASAR } \\
\text { EKOLOGI } \\
\text { (B) }\end{array}$ & $\begin{array}{c}\text { TINGGI } \\
\text { (B1) }\end{array}$ & A1 B1 & A2 B1 \\
\cline { 2 - 4 } & RENDAH & A1 B2 & A2 B2 \\
\hline
\end{tabular}

Keterangan:

$\begin{aligned} \text { Variabel Terikat (Y) } & =\text { Sikap tenaga kerja yang berwawasan } \\ & \text { lingkungan } \\ \text { Variabel Bebas (X1) } & =\text { Strategi Pelatihan } \\ \text { Faktor A1 } & =\text { Kunjungan Objek Kerja } \\ \text { Faktor A2 } & =\text { Diskusi Kelompok } \\ & \\ \text { Variabel Bebas (X2) } & =\text { Pengetahuan Konsep Dasar Ekologi } \\ \text { Faktor B1 } & =\text { Tinggi } \\ \text { Faktor B2 } & =\text { Rendah }\end{aligned}$

Gambar 2: Desain Eksperimen
Populasi sebagai unit analisis adalah tenaga kerja yang akan menjalani pelatihan di Balai Latihan Kerja Daerah Jakarta Barat. Sistem pengambilan sampel menggunakan sistem simple random sampling terhadap seluruh tenaga kerja yang terdaftar untuk mengikuti pelatihan di Balai Latihan Kerja Daerah Jakarta Barat dengan jumlah sampel yang diambil sebesar 60 (enam puluh peserta).

Tahap pertama, seluruh peserta akan menjalani pengukuran terhadap tingkat pengetahuan dasar ekologi untuk menentukan tingkat pengetahuan tinggi dan rendah. Tahap selanjutnya seluruh responden dibagi ke dalam dua kelompok yaitu kelompok A1 (untuk mengikuti strategi pelatihan kunjungan objek kerja) dan A2 (untuk mengikuti strategi pelatihan diskusi kelompok).

Teknik pengumpulan data dilakukan dengan menggunakan instrumen kuesioner yang diberikan kepada semua responden dengan pilihan jawaban menggunakan skala Likert. Sebelum digunakan sebagai alat pengumpul data, instrumen harus dilakukan uji cobakan untuk memenuhi syarat validitas dan reliabilitas.

Penelitian ini menggunakan tiga variabel, pengetahuan dasar ekologi dan strategi pelatihan sebagai variabel independen $X_{1}$ dan $X_{2}$, serta sikap berwawasan lingkungan sebagai variabel terikat $\mathrm{Y}$.

Analisis data yang dugunakan dalam penelitian ini terdiri atas dua bagian, yaitu analisis deskriptif dan analisis diferensial. Analisis deskriptif dilakukan dengan penyajian data melalui tabel distribusi frekuensi, diagram batang, rata-rata dan simpangan baku. Sedangkan pada analisis diferensial digunakan pada pengujian hipotesis statistik.

Sebelum dilakukan pengujian hipotesis, kelompok-kelompok data dilakukan pengujian normalitas dan homogenitas. Untuk uji normalitas digunakan uji Liliefors dan uji homogenitas digunakan uji Bartlett. Pengujian hipotesis statistik digunakan ANAVA (analisis varians) dengan membanding angka $F_{\text {hitung }}$ dengan $\mathrm{F}_{\text {tabel }}$ pada setiap faktor perlakuan (A dan B), dan interaksi antar faktor (A $\mathrm{x}$ B). Apabila dari pengujian menunjukan adanya interaksi antara $\mathrm{A} x$ $\mathrm{B}$, maka uji dilanjutkan dengan pengujian Tukey

\begin{tabular}{|l|l|l|l|}
\hline Volume XII & Nomor 02 & September 2011 & ISSN 1411-1829 \\
\hline
\end{tabular}


untuk mengetahui kebermaknaan interaksi tersebut.

Uji Tukey digunakan untuk mengetahui tingkat kebermaknaan yang berhubungan dengan variable atribut yaitu faktor B terhadap faktor A. Notasi yang diuji adalah pasangan sel $A_{1} B_{1}-A_{2} B_{1}$ dan $A_{1} B_{2}-A_{2} B_{2}$. Kebermaknaan diperoleh dengan membandingkan nilai $Q_{\text {hitung }}$ dan $\mathrm{Q}_{\text {tabel }}$.

\section{HASIL PENELITIAN DAN PEMBAHASAN}

Deskripsi data setiap variabel akan disajikan secara berturut-turut, yaitu deskripsi skor sikap tenaga kerja yang berwawasan lingkungan yang memperoleh strategi pelatihan kunjungan objek kerja dan strategi pelatihan diskusi kelompok, skor sikap tenaga kerja yang berwawasan lingkungan pada kelompok tenaga kerja yang mempunyai pengetahuan konsep dasar ekologi tinggi yang memperoleh strategi pelatihan kunjungan objek kerja dan strategi pelatihan diskusi kelompok, skor sikap tenaga kerja yang berwawasan lingkungan pada kelompok tenaga kerja yang mempunyai pengetahuan konsep dasar ekologi rendah yang diberi pelatihan dengan strategi kunjungan objek kerja dan strategi diskusi kelompok.
Rangkuman skor sikap tenaga kerja yang berwawasan lingkungan dapat dilihat pada Tabel 1.Untuk menguji hipotesis penelitian secara keseluruhan digunakan analisis varians (ANAVA) dua jalur pada taraf signifikansi 5\% $(\alpha=0,05)$. Kriteria pengujian adalah sebagai berikut: (1) jika untuk Antar Kolom skor F hitung lebih besar daripada skor F tabel (F-hit > F-tab), dinyatakan terdapat perbedaan yang signifikan; (2) jika untuk Antar Baris skor $\mathrm{F}$ hitung lebih besar dari pada skor Ftabel (F-hit > F-tab), dinyatakan terdapat perbedaan yang signifikan; dan (3) jika untuk Interaksi skor Fhitung lebih besar daripada skor Ftabel (F-hit > F-tab), dinyatakan terdapat perbedaan yang signifikan. Selanjutnya apabila diketahui terdapat interaksi maka dilanjutkan dengan uji Tuckey untuk mengetahui efek interaksi (simpel effect) mana yang lebih tinggi.

Hasil perhitungan analisis data dengan ANAVA dua jalur dari Sikap tenaga kerja yang berwawasan lingkungan dapat diikhtisarkan seperti pada Tabel 2.

Berdasarkan hasil perhitungan yang diikhtiarkan pada Tabel 4-10 di atas dapat dirumuskan hasil uji hipotesis sebagai berikut.

Tabel 1: Deskripsi Data Sikap Tenaga Kerja yang Berwawasan Lingkungan

\begin{tabular}{|c|c|c|c|c|}
\hline $\begin{array}{l}\text { Pengetahuan } \\
\text { Konsep Dasar } \\
\text { Ekologi }\end{array}$ & Keterangan & $\begin{array}{c}\text { Strategi Pelatihan } \\
\text { Kunjungan Objek } \\
\text { Kerja }\end{array}$ & $\begin{array}{l}\text { Strategi Pelatihan } \\
\text { Diskusi Kelompok }\end{array}$ & Total \\
\hline TINGGI & $\begin{array}{r}\text { Jum. Sampel }= \\
\text { Jumlah }= \\
\text { Rerata }= \\
\text { St Deviasi }= \\
\text { Varians }= \\
\text { Jml Kuadrat }=\end{array}$ & $\begin{array}{c}13 \\
2,270 \\
174.62 \\
3.31 \\
10.92 \\
396,508\end{array}$ & $\begin{array}{c}13 \\
2,030 \\
156.15 \\
7.08 \\
50.14 \\
317,594\end{array}$ & $\begin{array}{c}26 \\
4,300 \\
165.38 \\
10.86 \\
117.93 \\
714,102\end{array}$ \\
\hline RENDAH & $\begin{array}{r}\text { Jum. Sampel }= \\
\text { Jumlah }= \\
\text { Rerata }= \\
\text { St Deviasi }= \\
\text { Varians }= \\
\text { Jml Kuadrat }=\end{array}$ & $\begin{array}{c}13 \\
2,088 \\
160.62 \\
7.27 \\
52.92 \\
336,000\end{array}$ & $\begin{array}{c}13 \\
2,221 \\
170.85 \\
5.08 \\
25.81 \\
379,759\end{array}$ & $\begin{array}{c}26 \\
4,309 \\
165.73 \\
8.06 \\
65.00 \\
715,759\end{array}$ \\
\hline TOTAL & $\begin{array}{r}\text { Jum. Sampel }= \\
\text { Jumlah }= \\
\text { Rerata }= \\
\text { St Deviasi }= \\
\text { Varians }= \\
\text { Jml Kuadrat }=\end{array}$ & $\begin{array}{c}26 \\
4,358 \\
167.62 \\
9.03 \\
81.61 \\
732,508\end{array}$ & $\begin{array}{c}26 \\
4,251 \\
163.50 \\
9.62 \\
92.58 \\
697,353\end{array}$ & $\begin{array}{c}52 \\
8,609 \\
162.43 \\
24.60 \\
605.13 \\
1,429,861\end{array}$ \\
\hline
\end{tabular}


Keterangan:

$\begin{array}{ll}\mathrm{db} & =\text { derajat kebebasan } \\ \mathrm{JK} & =\text { Jumlah Kuadrat } \\ \mathrm{RJK} & =\text { Rata-rata Jumlah Kuadrat } \\ \star * & =\text { Uji F signifikan pada taraf signifikansi 0,01 } \\ \mathrm{nS} & =\text { non-significant }\end{array}$

Tabel 2. Anava Dua Jalur untuk Sikap Tenaga kerja yang Berwawasan Lingkungan

\begin{tabular}{|l|c|c|c|c|c|c|}
\hline $\begin{array}{l}\text { Sumber } \\
\text { Variansi }\end{array}$ & db & JK & RJK & F hitung & \multicolumn{2}{|c|}{ F tabel } \\
\hline $\begin{array}{l}\text { Antar } \\
\text { kelompok }\end{array}$ & 3 & $3,138.73$ & $1,046.24$ & $34.97^{* *}$ & 2.798 & 4.218 \\
\hline $\begin{array}{l}\text { Dalam } \\
\text { kelompok }\end{array}$ & 48 & $1,436.10$ & 29.92 & & & \\
\hline $\begin{array}{l}\text { Strategi } \\
\text { Pelatihan } \\
\text { (Kolom) }\end{array}$ & 1 & 220.17 & 220.17 & $7.36^{* *}$ & & \\
\hline $\begin{array}{l}\text { Pengetahuan } \\
\text { Konsep } \\
\text { Dasar } \\
\text { Ekologi } \\
\text { (Baris) }\end{array}$ & 1 & 1.56 & 1.56 & $0.05^{\text {Sn }}$ & 4.030 & 7.159 \\
\hline Interaksi & 1 & $2,917.00$ & $2,917.00$ & $97.50^{* *}$ & & \\
\hline Jumlah & $\mathbf{5 1}$ & $\mathbf{4 , 5 7 4 . 8 3}$ & & & & \\
\hline
\end{tabular}

Berdasarkan hasil analisis varians di atas, dapat dijelaskan sebagai berikut:

1. Terdapat pengaruh yang signifikan strategi pelatihan terhadap sikap tenaga kerja yang berwawasan lingkungan karena nilai F-hitung $=7.36>$ F-tabel $=4,03$ pada $\alpha=0,05$ dan $7,15 \alpha=0,01$.

2. Tidak terdapat pengaruh pengetahuan konsep dasar ekologi terhadap sikap tenaga kerja yang berwawasan lingkungan karena nilai F-hitung $=0.05<$ F-tabel $==4,03$ pada $\alpha=0,05$ dan $7,15 \alpha=0,01$.
3. Terdapat pengaruh interaksi yang signifikan antara strategi pelatihan dan pengetahuan konsep dasar ekologi terhadap sikap tenaga kerja yang berwawasan lingkungan karena nilai F-hitung $=97.50>$ F-tabel $==4,03$ pada $\alpha=0,05$ dan $7,15 \alpha=0,01$.

Untuk jelasnya, interaksi antara pengetahuan kosep dasar ekologi dengan strategi

\section{\begin{tabular}{|l|l|l|l|}
\hline Volume XII & Nomor 02 & September 2011 & ISSN 1411-1829 \\
\hline
\end{tabular}}




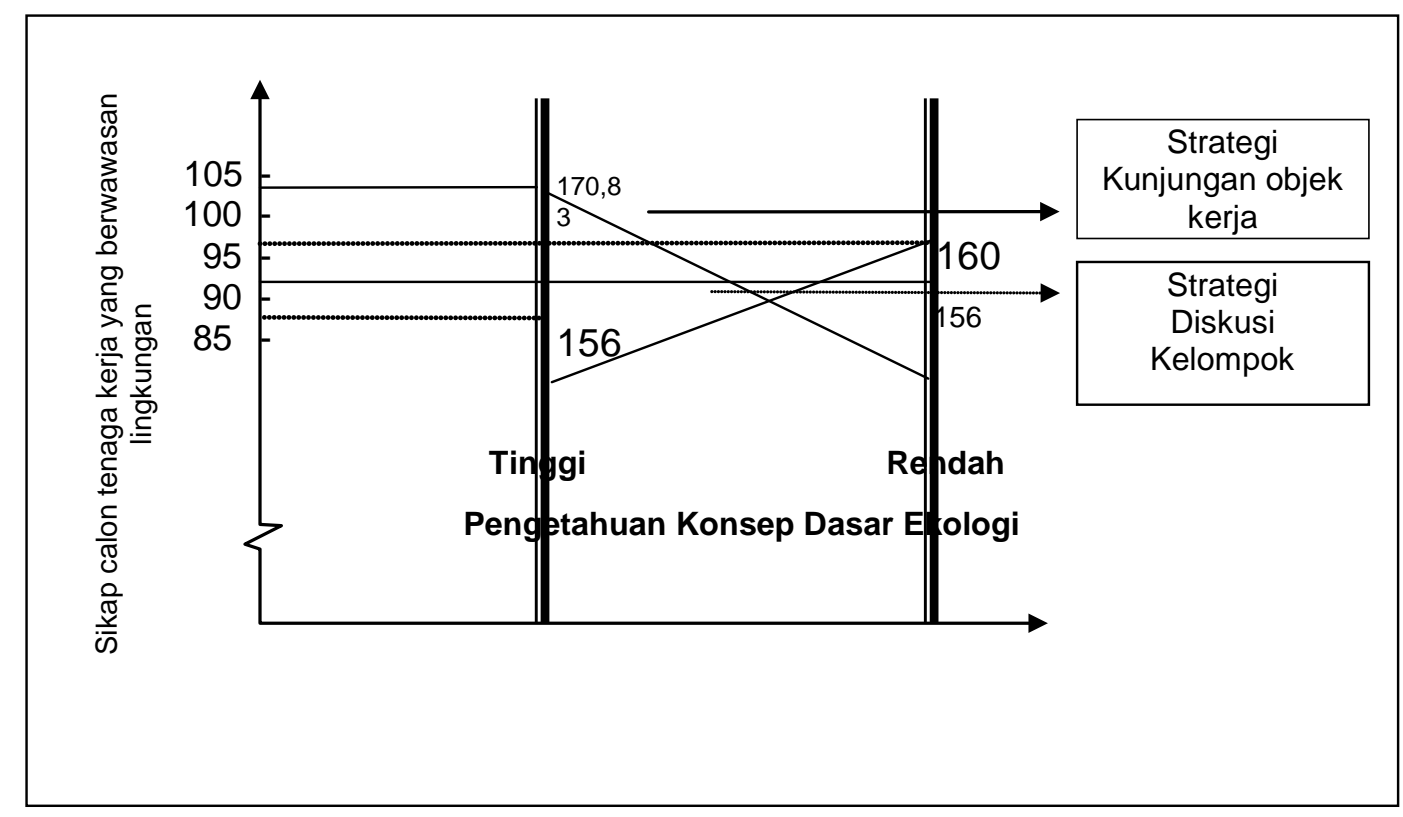

\section{Gambar 3. Visualisasi Interaksi Antara Strategi Pelatihan dengan Pengetahuan Konsep Dasar Ekologi Terhadap Sikap Tenaga kerja yang Berwawasan Lingkungan}

pelatihan terhadap sikap tenaga kerja yang berwawasan lingkungan dapat divisualisasikan melalui gambar di bawah ini:

Berdasarkan uji Anava tersebut di atas karena terdapat pengaruh yang signifikan dari factor perlakuan dan interaksinya, maka selanjutnya dilakukan pengujian uji lanjut hipotesis penelitian dengan menggunakan Uji Tuckey.

\section{Uji Hipotesis Pertama}

Perbedaan sikap tenaga kerja yang berwawasan lingkungan yang memperoleh strategi pelatihan kunjungan objek kerja dan diskusi kelompok

Hasil perhitungan ANAVA dua jalur menunjukkan bahwa terdapat interaksi antara strategi pelatihan dan konsep dasar ekologi

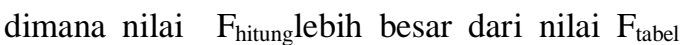
Ini berarti dapat dilanjutkan dengan uji Tuckey untuk menguji hipotesis.

Data hasil penelitian menunjukkan bahwa kelompok tenaga kerja yang mengikuti pelatihan dengan diterapkan stategi pelatihan kunjungan objek kerja memiliki skor rata-rata sebesar 167,62. Sedangkan kelompok tenaga kerja yang mengikuti pelatihan dengan diterapkan strategi diskusi kelompok memiliki skor rata-rata sebesar 163,50. dengan rata-rata jumlah kuadrat dalam pada uji ANAVA sebesar 29,92. Hasil uji Tuckey menunjukkan bahwa
$\mathrm{Q}_{\text {hitung }}=3,841$ lebih kecil dari pada $\mathrm{Q}_{\text {tabel }}=3,90$ atau $Q_{\text {hitung }}=3,841<Q_{\text {tabel }}=3,90$ Ini berarti

secara keseluruhan sikap tenaga kerja yang berwawasan lingkungan yang mengikuti pelatihan dengan strategi kunjungan objek kerja dan strategi diskusi kelompok tidak terdapat perbedaan yang signifikan terhadap sikap tenaga kerja yang berwawasan lingkungan.

\section{Tabel 3. Rangkuman Hasil Uji Tuckey Antar} Variabel

\begin{tabular}{|c|c|c|c|c|}
\hline $\begin{array}{l}\text { Pasangan } \\
\text { Kelompok } \\
\text { yang } \\
\text { Dibandingkan }\end{array}$ & $Q_{\text {hitung }}$ & $\begin{array}{l}\text { Qtab } \\
\text { el } \\
(0,05)\end{array}$ & $\begin{array}{l}Q_{\text {tabe }} \\
I(0,01)\end{array}$ & $\begin{array}{l}\text { Keterang } \\
\text { an }\end{array}$ \\
\hline$A_{1}$ dengan $A_{2}$ & $\begin{array}{l}3,841 \\
n s\end{array}$ & 3,90 & 4,74 & $\begin{array}{l}\mathrm{H}_{0} \text {. Terima } \\
\mathrm{H}_{1} \text { Tolak }\end{array}$ \\
\hline $\begin{array}{l}A_{1} B_{1} \text { dengan } \\
A_{2} B_{1}\end{array}$ & $\underset{* *}{12,175}$ & 4,15 & 5,64 & $\begin{array}{l}\mathrm{H}_{0} \text {. Tolak } \\
\mathrm{H}_{1} \text { Terima }\end{array}$ \\
\hline $\begin{array}{l}A_{1} B_{2} \text { dengan } \\
A_{2} B_{2}\end{array}$ & $\begin{array}{l}6,743^{*} \\
*\end{array}$ & 4,15 & 5,64 & $\begin{array}{l}\mathrm{H}_{0} \text {. Tolak } \\
\mathrm{H}_{1} \text { Terima }\end{array}$ \\
\hline
\end{tabular}

Keterangan

** = sangat signifikan

* = signifikan

ns = non signifikan

\begin{tabular}{|l|l|l|l|}
\hline Volume XII & Nomor 02 & September 2011 & ISSN 1411-1829 \\
\hline
\end{tabular}




\section{Uji Hipotesis Kedua}

Perbedaan sikap tenaga kerja yang berwawasan lingkungan yang memiliki pengetahuan konsep dasar ekologi tinggi yang memperoleh strategi pelatihan kunjungan objek kerja dan diskusi kelompok

Hasil perhitungan ANAVA dua jalur menunjukkan bahwa terdapat interaksi antara strategi pelatihan dan konsep dasar ekologi dimana skor $F_{\text {hitunglebih besar dari skor } F_{\text {tabel }}}$ Ini berarti dapat dilanjutkan dengan uji Tuckey untuk menguji hipotesis.

Data hasil penelitian menunjukkan bahwa kelompok tenaga kerja yang mengikuti pelatihan dengan diterapkan stategi pelatihan kunjungan objek kerja yang memiliki pengetahuan konsep dasar ekologi tinggi memiliki skor rata-rata sebesar 174,62. Sedangkan kelompok tenaga kerja yang mengikuti pelatihan dengan diterapkan strategi diskusi kelompok yang memiliki pengetahuan konsep dasar ekologi tinggi memiliki skor ratarata sebesar 156,150.dengan rata-rata jumlah kuadrat dalam pada uji Anava sebesar 29,92. Hasil uji Tuckey menunjukkan bahwa Qhitung = 12,175 lebih besar dari pada $\mathrm{Q}_{\text {tabel }}=4,15$ atau $\mathrm{Q}_{\text {hitung }}=12,175>\mathrm{Q}_{\text {tabel }}=4,15$ Ini berarti sikap tenaga kerja yang berwawasan lingkungan yang mengikuti pelatihan dengan strategi kunjungan objek kerja dan strategi diskusi kelompok terdapat perbedaan yang signifikan terhadap sikap tenaga kerja yang berwawasan lingkungan.

\section{Uji Hipotesis Ketiga}

Perbedaan sikap tenaga kerja yang berwawasan lingkungan yang memiliki pengetahuan konsep dasar ekologi rendah dan memperoleh strategi pelatihan kunjungan objek kerja dan diskusi kelompok

Hasil perhitungan ANAVA dua jalur menunjukkan bahwa terdapat interaksi antara strategi pelatihan dan konsep dasar ekologi dimana skor $F_{\text {hitunglebih besar dari skor } F_{\text {tabel }}}$ Ini berarti dapat dilanjutkan dengan uji Tuckey untuk menguji hipotesis.

Data hasil penelitian menunjukkan bahwa kelompok tenaga kerja yang mengikuti pelatihan dengan diterapkan stategi pelatihan kunjungan objek kerja yang memiliki pengetahuan konsep dasar ekologi rendah memiliki skor rata-rata sebesar 160,62. Sedangkan kelompok tenaga kerja yang mengikuti pelatihan dengan diterapkan strategi diskusi kelompok yang memiliki pengetahuan konsep dasar ekologi rendah memiliki skor ratarata sebesar 170,85. dengan rata-rata jumlah kuadrat dalam pada uji Anava sebesar 29,92. Hasil uji Tuckey menunjukkan bahwa $\mathrm{Q}_{\text {hitung }}=$ 6,743 lebih besar dari pada $\mathrm{Q}_{\text {tabel }}=4,15$ atau $\mathrm{Q}_{\text {hitung }}=6,743>\mathrm{Q}_{\text {tabel }}=4,15$ Ini berarti sikap tenaga kerja yang berwawasan lingkungan yang mengikuti pelatihan dengan strategi kunjungan objek kerja dan strategi diskusi kelompok terdapat perbedaan yang signifikan terhadap sikap tenaga kerja yang berwawasan lingkungan.

\section{Uji Hipotesis Keempat}

Interaksi antara strategi pelatihan dengan pengetahuan konsep dasar ekologi dalam pengaruhnya terhadap sikap tenaga kerja yang berwawasan lingkungan

Hasil uji hipotesis keempat menunjukkan bahwa terdapat pengaruh interaksi strategi pelatihan dengan pengetahuan konsep dasar ekologi terhadap sikap tenaga kerja yang berwawasan lingkungan. Hal ini ditunjukan hasil perhitungan ANAVA yang

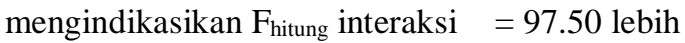
besar dari $\mathrm{F}_{\text {tabel }}=4,030$ atau $\mathrm{F}_{\text {hitung }}=97.50>$ $\mathrm{F}_{\text {tabel }}=4,030$ signifikansi 0,05 maupun pada taraf dan $\mathrm{F}_{\text {tabel }}=7,160$ pada taraf signifikansi 0,01. Hal ini berarti Ho ditolak dan $\mathrm{H}_{1}$ diterima, sehingga terdapat interaksi yang sangat signifikan.

\section{PEMBAHASAN HASIL PENELITIAN}

Dari seluruh kajian pengujian hipotesis di atas, bahwa keempat rumusan masalah, hipotesis statistik dan pengujiannya, terutama yang berkaitan dengan ketidaksesuaian antara hipotesis dan hasil penelitian, maka berikut ini akan dibahas sebagai berikut:

(1) Secara keseluruhan sikap tenaga kerja yang berwawasan lingkungan dan memiliki pengetahun konsep dasar ekologi baik memperoleh strategi pelatihan kunjungan objek kerja maupun strategi diskusi kelompok tidak menunjukkan perbedaan.

\begin{tabular}{|l|l|l|l|}
\hline Volume XII & Nomor 02 & September 2011 & ISSN 1411-1829 \\
\hline
\end{tabular}


Berdasarkan hasil uji hipotesis pertaman strategi pelatihan kunjungan objek kerja dan diskusi kelompok serta pengetahuan tenaga kerja tentang konsep dasar ekologi sebagai variabel atribut dalam penelitian ini, walaupun secara teoritis dapat mempengaruhi faktor sikap tenaga kerja yang berwawasan lingkungan, namun penelitian ini tidak menunjukan perbedaan yang bermakna. Hal ini banyak disebabkan oleh pengaruh perbedaan skor pengetahuan konsep dasar ekologi yang tidak kontras antara tenaga kerja yang mempunyai pengetahuan konsep dasar ekologi.

Kondisi realias tersebut di atas tentang strategi pelatihan kunjungan objek kerja dan diskusi kelompok menunjukan kisaran skor tidak berbeda. Ini dapat disebabkan oleh adanya kesamaan kesempatan dalam pengalaman peserta sebelumnya dengan kegiatan-kegiatan pelatihan. Walaupun demikian tidak menutup kemungkinan bahwa instrumen yang digunakan dalam pengukuran sikap tenaga kerja yang berwawasan lingkungan kurang sesuai untuk diterapkan pada situasi peserta pelatihan dan keadaan pada penelitian ini.

(2) Perbedaan sikap tenaga kerja yang berwawasan lingkungan yang memiliki pengetahuan konsep dasar ekologi tinggi dan memperoleh strategi pelatihan kunjungan objek kerja dan strategi diskusi kelompok.

Dari pengujian hipotesis penelitian kedua diperoleh bahwa terdapat perbedaan sikap tenaga kerja yang berwawasan lingkungan yang memiliki pengetahuan konsep dasar ekologi tinggi, antara yang memperoleh strategi pelatihan kunjungan kerja dan strategi diskusi kelompok. Hasil analisis menunjukkan bahwa strategi pelatihan kunjungan objek kerja dan kelompok yang memimiliki pengetahuan konsep dasar ekologi tinggi memberikan hasil yang lebih tinggi dari pada kelompok tenaga kerja yang berwawasan lingkungan dan memperoleh strategi pelatihan diskusi.

Berdasarkan perbedaan ini dapat dijelaskan tentang keunggulan strategi pelatihan kunjungan objek kerja dan strategi diskusi kelompok pada tenaga kerja memiliki pengetahuan konsep dasar ekologi tinggi. Strategi pelatihan kunjungan objek kerja memproses dan memperkenalkan pelaksanaan pekerjaan kepada tenaga kerja yang berdasarkan pengetahuan konsep dasar ekologi mereka di dalam kehidupan sehari-hari, sehingga melalui pengetahuan awal tentang konsep dasar ekologi mereka mampu menghubungkan pengetahuan awal tersebut dengan materi pelatihan yang mampu merubah sikap tenaga kerja yang berwawasan lingkungan

Sikap tenaga kerja yang berwawasan lingkungan tenaga kerja yang memiliki pengetahuan konsep dasar ekologi tinggi adalah hasil perubahan sikap setelah menerima materi pelatihan melalui strategi pelatihan kunjungan objek kerja dalam rangka menganalisis, mempertimbang-kan/menafsir, dan merangkum informasi baru yang diterima dalam kunjungan objek kerja sehingga terbentuk sikap baru dalam kehidupan sehari-hari, yakni sikap yang berwawasan lingkungan. Strategi pelatihan kunjungan objek kerja mampu memberikan pencerahan kepada mereka, mencari informasi baru menyesuaikan sendiri untuk dikembangkan serta mampu merubah sikap tenaga kerja secara optimal.

Strategi pelatihan diskusi kelompok dapat berlangsung kurang efektif pada tenaga kerja yang memiliki pengetahuan konsep dasar ekologi materi pelatihan disampaikan dengan cara memberikan kesempatan kepada mereka dengan mengandalkan penyampaian ide atau gagasan-gagasan baru berdasarkan pengetahuan konsep dasar ekologi. Dengan strategi pelatihan diskusi kelompok dapat membantu tenaga kerja dalam proses pengkajian terhadap lingkungan karena berbagaimanapun konsep yang diberikan jika tidak diperkenalkan dengan objek yang sebenarnya maka akan mengurangi pembentukan sikan tenaga kerja yang berwawasan lingkungan.

Oleh karena itu, walaupun kedua strategi pelatihan memiliki kemampuan membentuk sikap tenaga kerja yang berwawasan lingkungan, tetapi strategi pelatihan kunjungan objek kerja tetap akan dapat memberikan hasil yang lebih baik daripada strategi diskusi kelompok. Bagi tenaga kerja yang memiliki pengetahuan konsep dasar ekologi tinggi.

Berdasarkan temuan yang diperoleh dari hasil penelitian ini, dapat dinyatakan 
bahwa, strategi pelatihan kunjungan objek kerja pada tenaga kerja yang memiliki pengetahuan konsep dasar ekologi tinggi dalam pembentukan sikap berwawasan lingkungan lebih efektif dari pada strategi pelatihan diskusi kelompok.

(3) Perbedaan sikap tenaga kerja yang berwawasan lingkungan yang memiliki pengetahuan konsep dasar ekologi rendah dan memperoleh strategi pelatihan kunjungan objek kerja dan strategi diskusi kelompok.

Dari pengujian hipotesis penelitian ketiga diperoleh bahwa terdapat perbedaan sikap tenaga kerja yang berwawasan lingkungan yang memiliki pengetahuan konsep dasar ekologi rendah, antara yang memperoleh strategi pelatihan kunjungan kerja dan strategi diskusi kelompok. Hasil analisis menunjukkan bahwa strategi pelatihan diskusi kelompok yang memimiliki pengetahuan konsep dasar ekologi rendah memberikan hasil yang lebih baik dari pada kelompok tenaga kerja yang berwawasan lingkungan yang memiliki pengetahuan konsep dasar ekologi rendah dan memperoleh strategi kunjungan objek kerja.

Berdasarkan perbedaan ini dapat dijelaskan tentang keunggulan strategi pelatihan diskusi kelompok pada tenaga kerja memiliki pengetahuan konsep dasar ekologi rendah. Strategi pelatihan diskusi kelompok memproses dan menerima hasil diskusi yang menjadi kesepakatan bersama yang berdasarkan pengetahuan konsep dasar ekologi yang rendah, sehingga melalui pengetahuan awal tentang konsep dasar ekologi mereka mampu menghubungkan pengetahuan awal tersebut dengan materi pelatihan yang mampu merubah sikap tenaga kerja yang berwawasan lingkungan

Sikap tenaga kerja yang berwawasan lingkungan yang memiliki pengetahuan konsep dasar ekologi rendah adalah hasil perubahan sikap setelah menerima materi pelatihan melalui strategi pelatihan diskusi kelompok dalam rangka menganalisis, mempertimbangkan/menafsir, dan merangkum informasi baru yang diterima hasil keputusan bersama sehingga terbentuk sikap baru dalam kehidupan sehari-hari, yakni sikap yang berwawasan lingkungan. Strategi pelatihan diskusi kelompok mampu memberikan pencerahan kepada mereka, mencari informasi baru menyesuaikan sendiri untuk dikembangkan serta mampu merubah sikap tenaga kerja secara optimal.

Strategi pelatihan kunjungan objek kerja berlangsung kurang efektif pada tenaga kerja yang memiliki pengetahuan konsep dasar ekologi rendah karena materi pelatihan disampaikan dengan cara membawa mereka ke objek kerja dengan mengandalkan analisa dan gagasan-gagasan sendiri berdasarkan pengetahuan konsep dasar ekologi. Dengan strategi pelatihan kunjungan objek kerja dapat membantu tenaga kerja dalam proses pengkajian terhadap lingkungan karena berbagaimanapun konsep yang diberikan jika mengandalkan kemampuan sendiri maka akan mengurangi pembentukan sikap tenaga kerja yang berwawasan lingkungan.

Oleh karena itu, walaupun kedua strategi pelatihan memiliki kemampuan membentuk sikap tenaga kerja yang berwawasan lingkungan, tetapi strategi pelatihan diskusi kelompok pada tenaga kerja yang memiliki pengetahuan konsep dasar ekologi rendah tetap akan dapat memberikan hasil yang lebih baik daripada strategi kunjungan objek kerja pada tenaga kerja yang memiliki pengetahuan konsep dasar ekologi rendah.

Berdasarkan temuan yang diperoleh dari hasil penelitian ini, maka dapat dinyatakan bahwa, strategi pelatihan diskusi kelompok pada tenaga kerja yang memiliki pengetahuan konsep dasar ekologi rendah dalam pembentukan sikap berwawasan lingkungan lebih efektif dari pada strategi pelatihan kunjungan objek kerja.

(4) Pengaruh Interaksi antara pengetahuan konsep dasar ekologi dan strategi pelatihan terhadap sikap tenaga kerja yang berwawasan lingkungan.

Dari pengujian hipotesis penelitian keempat diperoleh bahwa terdapat pengaruh interaksi antara pengetahuan konsep dasar ekologi dan strategi pelatihan terhadap sikap tenaga kerja yang berwawasan lingkungan menunjukkan adanya pengaruh yang signifikan. Hal ini mengindikasikan bahwa, ketepatan suatu strategi pelatihan berhubungan erat dengan pengetahuan konsep dasar ekologi dan 
karakteristik tenaga kerja yang mengikuti pelatihan. Temuan ini memberikan makna bahwa pengetahuan konsep dasar ekologi memberikan efek terhadap perlakuan eksperimental yakni strategi pelatihan yang melalui strategi objek kunjungan kerja dan strategi diskusi kelompok secara efek, selanjutnya berpengaruh terhadap hasil pelatihan dalam bentuk sikap tenaga kerja yang berwawasan lingkungan. Selain itu, menjelaskan pula bahwa ketepatan strategi pelatihan berhubungan erat dengan karakteristik tenaga kerja yang mengikuti pelatihan untuk merubah pola sikap mereka yang berwawasan lingkungan.

\section{KESIMPULAN IMPLIKASI DAN SARAN}

\section{Kesimpulan}

Penelitian ini menggunakan metode eksperimen yang bertujuan untuk mengetahui perbedaan sikap tenaga kerja yang berwawasan lingkungan melalui strategi pelatihan kunjungan objek kerja dan strategi diskusi kelompok dan pengetahuan konsep dasar ekologi Berdasarkan hasil pengujian hipotesis dan temuan penelitian maka dapat disimpulkan sebagai berikut:

1. Secara keseluruhan sikap tenaga kerja yang berwawasan lingkungan tidak terdapat perbedaan antara yang memperoleh strategi pelatihan kunjungan objek kerja dengan strategi pelatihan diskusi kelompok.

2. Sikap tenaga kerja yang berwawasan lingkungan kelompok yang memiliki pengetahuan konsep dasar ekologi tinggi, dan memperoleh strategi pelatihan kunjungan objek kerja lebih baik daripada yang memperoleh strategi pelatihan diskusi kelompok.

3. Sikap tenaga kerja yang berwawasan lingkungan kelompok yang memiliki pengetahuan konsep dasar ekologi rendah, dan memperoleh strategi pelatihan diskusi kelompok lebih baik daripada yang memperoleh strategi pelatihan kunjungan objek kerja.

4. Terdapat interaksi antara strategi pelatihan dan pengetahuan konsep dasar ekologi terhadap sikap tenaga kerja yang berwawasan lingkungan.
Berdasarkan kesimpulan tersebut maka dapat dinyatakan bahwa perubahan sikap tenaga kerja yang berwawasan lingkungan, diperlukan pemilihan strategi pelatihan yang tepat dan efisien dengan mempertimbangkan pengetahuan konsep dasar ekologi.

\section{Implikasi}

Penyusutan nilai-nilai lingkungan hidup dalam proses aktivitas manusia merupakan tantangan bagi perjuangan terhadap pola-pola kehidupan untuk secara utuh dapat membangun karakter manusia yang berkualitas. Salah satu karakter yang dibutuhkan adalah pola pelatihan yang mampu membangun sikap tenaga kerja yang berwawasan lingkungan dalam memasuki dunia kerja.

\section{Implikasi kebijakan}

Terbentuknya sikap tenaga kerja yang berwawasan lingkungan ini akan menjadi bentuk investasi pengembangan sumber daya manusia yang akan berkompetisi di dunia kerja pada era globalisasi yang memperhatikan keberlanjutan lingkungan, dan juga membangun sumber daya manusia yang berwawasan lingkungan dalam pelaksanaan pembangunan yang berkelanjutan.

Sikap tenaga kerja yang berwawasan lingkungan sebagai salah satu bagian dalam pengembangan sumber daya manusia yang memperhatikan keberlanjutan lingkungan, tidak akan terlepas dari kegiatan diklat yang menyelenggarakan pelatihan tenaga kerja dalam memperkuat kapasitas untuk di terapkan pada dunia kerjanya.

\section{Implikasi Teoretik}

Implikasi dari hasil penelitian ini adalah sebagai berikut:

Pertama, secara umum penerapan strategi pelatihan kunjungan objek kerja pada pelatihan yang berkaitan dengan sikap tenaga kerja yang berwawasan lingkungan. Untuk itu penyusunan program strategi pelatihan kunjungan objek kerja harus dilakukan secara proporsional dengan memperhatikan konsep dasar ekologi dalam pencapaian target pembentukan sikap yang berwawasan lingkungan. 
Kedua, penerapan strategi pelatihan kunjungan objek kerja sangat ditentukan oleh peranan instruktur, sehingga kualitas instruktur dalam merancang program pelaksanaan strategi pelatihan, dan mengevaluasi suatu kegiatan kunjungan objek kerja perlu dikembangkan. Aspek-aspek yang menjadi perhatian adalah tipe dan kondisi objek kerja yang akan dijadikan obyek sasaran strategi pelatihan tenaga kerja sebagai peserta pelatihan, dan mempersiapkan modul kegiatan pelatihan yang terukur.

Ketiga, adanya strategi pelatihan kunjungan objek kerja yang efektif akan berkaitan dengan perbaikan objek kerja yang dikunjungi yang selama ini masih melaksanakan pola kerja yang belum mengarah pada peningkatan kualitas lingkungan.

\section{Saran}

Berdasarkan hasil penelitian ini, maka dapat dikemukakan saran-saran dalam penyelengaraan pelatihan di Balai Latihan Kerja, yakni:

Pertama, Manajemen Balai Latihan Kerja Daerah hendaknya mendorong dan menyediakan fasilitas dan akses, serta kesempatan baik bersifat operasional danlegalitas dalampenyelenggaran strategi pelatihan kunjungan objek kerja pada mata tataran yang menumbuhkan pencapaian sikap tenaga kerja yang berwawasan lingkungannya.

Kedua, para instruktur yang berkompetensi terhadap pelaksanaan strategi pelatihan kunjungan objek kerja diharapkan dapat mengikuti kegiatan pendidikan latihan tentang perancangan, pelaksanaan, dan evaluasi kegiatan kunjungan objek kerja Selain itu sebaiknya secara personal dapat melakukan hubungan eksternal dengan kelembagaan lain yang mampu memberikan wawasan tentang penyelenggaraan strategi pelatihan kunjungan objek kerja yang efektif.

Ketiga, Kelembagaan yang berorientasi pada pengembangan kualitas sumber daya manusia terutama balai-balai diklat perlu memerankan kegiatan penting dalam memberikan perubahan sikap terhadap pengelolaan lingkungan hidup sebaik tolok ukur keberhasilan pendidikan dalam dunia kerja.
Keempat, bagi para peneliti bahwa penelitian ini perlu dilakukan penelitian lebih lanjut tentang berbagai desain eksperimen dalam pengaruhnya terhadap sikap yang berwawasan lingkungan yang tepat dan terintegrasi pada kurikulum pelatihannya.

\section{Daftar Pustaka}

Anon., Dale's Cone of Experience, www.compstrategies.com

Badan Pusat Statistik, Penduduk Indonesia Hasil Sensus Penduduk 2000.Jakarta: Wifma Krida Makmur, 2000

Baron, Robert A. and Byrne, Donn.,Social Psychology, Under-standing Human Interaction, London: Allyn and Bacon, 1999.

Barrow, C.J., Environmental Manage-ment for Sustainable Develop-ment, London: Routledge, 2006

Bloom, Bunjamin S., Taxonomy of Educational Objectives Book 1 Cognitive Domain, New York: Logman Inc, 1954.

Borg, Walter D., and Gall, Meredith D., Educational Research, and introduction, $4^{\text {th }}$ Ed., New York: Kongman, 1983.

BPS/Sakernas., 2007 (www.nakertrans.go.id)

Campbell, Donald T., The Indirect Assessment of Social Attitudes', Attitude theory and measurement, ed. Martin Fishbein, (New York: John Wiley and Sons, 1967).

Capon, J. Anthony., Elementary Statistics for the Social Science, Belmont: Wadsworth, 1988.

Child, J. Organizational Structure, Environment and Performance: The Role of Strategic Choice, Sociology, 2000.

Chiras, Daniel D., Environmental Science $2^{\text {nd }}$ editionA Framework for Decision Making, California: The Benjamin/Cumming Publishing Company, 1987

Darwis, Sidi Sjah Djohan.,Studi Kondisi Mobilitas Penduduk dan Tenaga Kerja di Pedesaan, Puslibang Depnakertrans, (www.nakertrans.go,id; 2008) 
Departemen

Pendidikan

Nasional.Penyempurnaan Kurikulum 1994 SMU Jakarta: Depdiknas, 2000.

Efendi, Sofian., Sairin, Syafri., dan Dahlan, M. Alwi (ed), Membangun Martabat Manusia. Yogjakarta: Gajah Mada University Press, 1992, Gomes, Faustino Cardoso, Manajemen Sumber Daya Manusia, Yogyakarta: Andi Offset, 2000.

Holahan,Charles J., Environmental psychology. New York: Random House, 1982.

Jinghan, ML, 1999. Ekonomi Pembangunan dan Peren-canaan. Jakarta: Raja Grafindo Persada.

Jones, Anthony S., Bagford, Lawrence W., Wallen, Edward A., Strategies for teaching, New York: the Scarecrow Press. Inc, 1979.

Krathwohl, David R., Bloom, Benjamin S., Masia, Bertram B., Taxonomy of Educational Objectives., the classification of educational goals, Handbook II: Affective Domain, New York: David McKay Company, 1972.

Krech, David., Crutchfield, Richard and Ballacey, Egerton L., Individual in Society. Tokyo: McGraw-Hill Kogakusha, 1962

Lie, Anita., Cooperative Learning: Mempraktikkan Cooperative Learning di Ruang Kelas, Jakarta: Gramedia Widia-sarana Indonesia, 2002.

Malim, Tony and Birch,Ann, Social psychology. Houndmills: MacMillan Press, 1989.

Mangkuprawira, Sjafri.,Manajemen Sumber Daya Manusia Strategik, Jakarta: Gahlia Indonesia, 2002.

Mesarovic, Mihajlo

and Pestel,Edward.,Mankind at The Turning Point. The Second Report to the Club of Rome.New York: EP Dutton and Co. Inc., 1974.

Morgan, Clifford $\mathrm{T}$. et al, Introduction to Psychology., New York: McGraw-Hill Book Company, 1987.

Muller, Daniel J.,Measuring Social Attitudes: A Handbook Researcher and Practioners, New York: Teacher College Press, 1989.
Nebel, Bernard J. and Wright, Richard. T., Environmental Science, Seventh Edition, New Jersey: Prentice Hall, Inc, 2000.

Nitisemito, Alex S,.Manajemen Perso-nalia: ManajemenSumber Daya Manusia.Jakarta: Ghalia Indonesia, 1996.

Oskamp, Stuart.,Attitude and Opinion., Engelwood: New Jersey: Prentice Hall, Inc, 1997.

Powis, Kelli.,The Field Trip as an Active Learning Strategy: Task in Science and Engineering, Teaching Options Pedagogi-ques, Vol 3 No.1, February, 1999,http//www.uotawa.ca/academic/c ut/options/Feb_99/Fieldtrip_en.htm.

Ranupandojojo, Heidjrachman dan Husnan, Suad.,Manajemen Personalia.Edisi 4. Yogya-karta: BPFE, 1990.

Resosoedarmo, Soedjiran., Kartawinata,Kuswata., dan Soegiarto, Aprilani. Pengantar Ekologi. Jakarta: Etasa Dinamika, 1985.

Rukky, Achmad S., SDM Berkualitas: Mengubah Visi menjadi Realitas. Jakarta: Gramedia Pustaka Utama, 2003.

Sears,David O., Freedman Jonatan L., and Peplau,L. Anne., Psikologi Sosial, terjemahan Michael Adryanto. Jakarta: Erlangga, 1992.

Soerjani, Mohamad., Ekologi Manusia., Jakarta: Departemen Pendidi-kan Nasional, Universitas Terbuka, 2002.

Sprague, Elmer., Taylor, Paul W., Knowledege and Value. New York: Harcourt, Brace and World Inc, 1959.

Sudjana, Metode Statistika, Bandung: Tarsito, 1986.

Sumarwoto, Otto., Ilmu Lingkungan., Bandung: ITB, 1994.

Suriasumantri, Jujun S., Filsafat Ilmu, Sebuah Pengantar Populer., Jakarta: Pustaka Sinar Harapan, 1998.

Todaro, Michael P., Ekonomi Pembangunan di Dunia ketiga.Jakarta: Erlangga, 1999.

\begin{tabular}{|l|l|l|l|}
\hline Volume XII & Nomor 02 & September 2011 & ISSN 1411-1829 \\
\hline
\end{tabular}

